\title{
Trust-based social capital, economic growth and property rights: Explaining the relationship
}

\author{
Mahyudin Ahmad*a, Stephen G Hall ${ }^{\mathrm{b}}$ \\ (Forthcoming in International Journal of Social Economics, IJSE)
}

\begin{abstract}
:
Previous studies on social capital are able to show its significant growth-effect, however the majority of studies are in cross-sectional setting, and the widely used measure of social capital is generalized trust variable. Using panel estimation technique which hitherto has been limited in social capital studies, we show that generalized trust data obtained by the World Value Survey (WVS) are unable to yield sufficiently robust results in panel estimation due to missing observations problem. Subsequently, we propose a number of trust-alternative variables to proxy for social capital and re-estimate its effect on growth and property rights. The results improve significantly and we are able to show that social capital is a deep determinant of growth and it is affecting growth via property rights channel. The findings also give supporting evidence to the primacy of informal rules and constraints as proposed by North (2005) over the political prominence theory by Acemoglu, Johnson, \& Robinson (2005). The results partially confirm the findings by Williamson \& Kerekes (2011) on the underlying determinants of property rights and provide empirical support to the Clague, Keefer, Knack, \& Olson (1999)'s argument of positive relationship between contract intensive money and property rights.
\end{abstract}

Keywords: Social capital, property rights, growth, trust, panel data analysis.

JEL code: O43

\section{Introduction}

Ever since the studies by Coleman (1988) and Putnam (1993), the burgeoning literature thereafter has constantly confirmed social capital's significant impacts on economic development. In general, social capital is shown to have caused economic growth by creating a vibrant economic environment through lower transaction and monitoring costs, facilitating information flows and raising confidence in the regulatory capacity of public institutions. We however argue these are essentially the characteristics of a secure property rights environment (see literature review section for more discussion). It is interesting to note that majority of studies on social capital are in cross-sectional setting and the most widely used measure of social capital is generalized trust obtained from the World Value Survey (WVS).

\footnotetext{
* Corresponding author. Email: mahyudin@perlis.uitm.edu.my, mahyudin_77@yahoo.com.

${ }^{a}$ Mahyudin Ahmad is grateful to his PhD advisor, Professor Stephen G. Hall for his continued support in publishing this paper. He kindly thanks the participants at the International Conference on Economics and Business Research (ICEBR) 2013 for their supportive remarks. His gratitude extends to IJSE Editors and the referees involved in this paper. All remaining errors are his.

${ }^{\mathrm{b}}$ Stephen Hall acknowledges the support of ESRC-DFID Growth Programme (Award number RS10G0066).
} 
This paper departs from the commonly used cross-sectional setting and uses panel estimation technique instead. Two objectives motivate this study; firstly, we aim to attest whether generalized trust variable is the best proxy for social capital in explaining the latter's effect on economic growth in a panel setting. Via a specially formulated theoretical framework, we also test whether the growtheffect of social capital is direct or indirect, and if it is indirect, can property rights be the link between

social capital and growth. Our results show that generalized trust dataset provided by the WVS are unable to perform robustly in panel estimation due to severe missing observations problem. When we assume trust as the underlying unobserved time-invariant heterogeneity factor and omit the trust variable from the panel estimation, the results improve significantly. On the other hand, if we suppose there is sufficient variations in the trust data and include the trust variable in the estimation, the results deteriorate ${ }^{1}$.

This results bring us to the second objective. We seek to propose a number of trust-alternative variables to proxy for social capital, and re-estimate its effect on growth and property rights by using these alternative variables. We show that, based on theoretical arguments drawn from previous studies, variables such as corruption, ethnic tensions, contract intensive money and income inequality contain an element of trust. Our findings show that social capital variables significantly affect economic growth in the countries under study and the impacts essentially run via property rights channel. In other words, social capital contributes to the existence of a secure property rights environment that matters for growth.

In general, this study extends the existing evidence of significant growth-effect of social capital via panel analysis. In particular, this study contributes to the social capital literature in three ways. First, it shows that the widely used WVS's generalized trust data are unable to yield sufficiently robust results in panel estimation due to missing observations problem. Second, it proposes a number of trustalternative variables to proxy for social capital and the results improve significantly. Finally, these trust-alternative variables have greater explanatory power to explain the property rights channel through which they determine growth.

The remainder of this paper is organized as follows: Section 2 discusses the literature on institutional theory particularly that of property rights and social capital, the findings of the previous studies on social capital and the measurements used, as well as the references for the proposed trust-alternative variables. Section 3 outlines the theoretical framework, estimation strategy and data sources. Section 4 discusses the estimation results and Section 5 concludes.

\section{Literature review}

\section{Background of institutional theory: Property rights vs. social capital}

Arguably North (1990) is the pioneer who suggested institutions as a primary cause of economic development and he advocates that they matter for both long and short term growth. North defines institutions as the following: "Institutions are the rules of the game in a society or, more formally, are the humanly devised constraints that shape human interaction." He goes on to emphasize the key implications of institutions as: "...in consequence they structure incentives in human exchange, whether political, social, or economic."

The constraints suggested by North range from formal to informal, such as constitutions and laws governing economics and politics as well as unwritten taboos, customs, and traditions. The structure of both formal and informal rules and the character of their enforcement actually define the incentives

\footnotetext{
${ }^{1}$ Although trust is commonly assumed constant over times (see Putnam, 1993; Knowles, 2005; and Tabellini, 2007), our simple calculation of overall change in trust for all countries under study shows that there are notable variations in the trust dataset. See Table 1 in the next section.
} 
and wealth-maximizing opportunities of individuals and organizations. The institutional framework affects growth because it is integral to the amount spent on both the costs of transactions and the costs of transformation in the production process. A basic structure of property rights that encourages longterm contracting is undoubtedly essential for the creation of capital markets and economic growth (Aron, 2000). North's definition of institutions, specifically with respect to property rights institutions, has thereafter led to burgeoning literature examining the effect the formal constraints and incentives on the economic development.

However, recent trend shows there are increasing number of scholars who have shifted their attention away from institutions limited to formal constraints and incentives (property rights institutions). Stiglitz (2000) explains "the view that (formal) institutions arise to fill gaps in the market, and thereby increase economic efficiency, sometimes called the early North view, became very strongly held for a short while in North America. North has now rejected it, but many of his early disciples, including some in the international financial institutions, still believe in it."

In his later work, North (2005) himself contributes to widen the usual approach to institutions with the conception of a structure called the institutional matrix composed by formal rules and constraints, and informal enforcement characteristics. He argues this institutional matrix defines the set of incentives and opportunities in a given society and actors make choices based on subjective mental models (like belief) which underlie its manifestation (the explicit formal rules and constraints). He contends while manifestation of the belief into formal rules and constraints are now seriously considered, the belief itself i.e. the informal rules and constraints like norms and culture are equally important to its formal counterparts.

This theme continues to receive much interest by institutional economists and their studies are able to show robust and significant contributions of informal institutions in promoting cooperation, preparing contracting parties for their future decisions and actions and eventually determining the economic activities and production process.

However, the "definition" obstacle remains. It is very difficult to ascribe a specific definition to the informal institutions and researchers have come up with many different definitions, such as social capital, trust, norms and traditions, and relation-based governance. Knowles (2005) argues that the concept of informal institutions is a similar notion to what many researchers call social capital, but nevertheless he acknowledges the difficulties in defining and identifying its contribution at the macro level (see for example Durlauf \& Fafchamps (2005), Knowles (2005) and Sobel (2002)).

Coleman (1988) is arguably the first to introduce the term "social capital" and he defines it as "obligations and expectations, information channels, and social norms. In his later work, (Coleman, 1990) defines it as "some aspect of social structure that enables the achievement of certain ends that would not be attainable in its absence." Putnam (1993) -one of the earliest and widely cited studies on social capital- defines social capital as "the features of social organisation, such as trust, norms, and networks that can improve the efficiency of the society." Another widely cited definition is by Knack and Keefer (1997) i.e. "trust, cooperative norms, and networks between individuals." Fukuyama, (1999) suggests social capital can be defined as "an instantiated set of informal values or norms shared among members of a group that permits them to cooperate with one another. If members of the group come to expect that others will behave reliably and honestly, then they will come trust one another." Serageldin (1999) argues social capital is "the glue that holds societies together" and "without it no economic growth or human well-being is possible".

\section{Social capital and growth}


According to a meta-analysis study by Westlund \& Adam (2010) on 65 studies of social capital, the majority of the studies are in cross-sectional settings and the most widely used measure of social capital is generalized trust variable obtained from the World Value Survey (WVS).

Empirical studies finding robust positive impact of social capital, measured by trust variable obtained from the WVS or other comparable surveys, on economic growth are such as Berggren, Elinder, \& Jordahl (2008), Beugelsdijk, de Groot, \& van Schaik (2004), Bjørnskov (2006), Dincer \& Uslaner (2010), Knack \& Keefer (1997), Knowles (2006), La Porta, Lopez-de-Silanes, Shleifer, \& Vishny (1999), Neira, Vászquez, \& Portela (2009), Tabellini (2010), Whiteley (2000), and Zak \& Knack (2001).

The main argument supporting trust as an important determinant of economic growth is that trust is often referred to as a factor that serves to expand market activities since people will enter into economic exchanges with anyone as a result of trusting large number of individuals and more importantly trusting the people they do not necessarily know. This is called generalized, or thin, or interpersonal trust. Thus, the positive growth-effects of trust, or social capital in general, are such that it contributes to increasing number of mutually beneficial trades, reducing monitoring and transaction costs, solving collective action problems, and improving information flows that will eventually spur economic activities and improve economic performance (see Knack and Keefer (1997), Whiteley (2000), Knowles (2006) and Roth (2009)).

Apparently the above characteristics caused by social capital are among the key traits of an environment frequently associated with secure property rights.

Nevertheless, there are also a number of studies finding negative or no relationship between trust and growth. See for example Helliwell (1996) -who find negative relationship, and Beugelsdijk \& van Schaik (2005) and Raiser (2008) -no significant relationship.

A few recent studies such as Pérez-García, Montesinos, \& Fernandez de Guevara Radoselovics, (2006), Roth (2009), Baliamoune-Lutz (2011) and Hall \& Ahmad (2013) have departed from the cross-sectional setting and they instead use panel estimation technique. Nevertheless, Roth (2009) finds negative effect of trust on growth, Hall \& Ahmad (2013) no significant relationship, while PérezGarcía et al. (2006) and Baliamoune-Lutz (2011) use non-trust measures of social capital in their panel analysis.

\section{Measurements of social capital variable}

Generalized trust variable has been the frequently used measure of social variable, and its data are obtained from the World Value Survey (WVS). The data are gathered via waves of survey and each wave runs for about 4-5 years. During the period from 1981 to 2008, there are five waves altogether ${ }^{2}$. In other words, the maximum number of observation per country, if the country is covered in all waves, is five. Hence, the weaknesses of the dataset when they are estimated in panel ${ }^{3}$.

Subsequently, this study extends the analysis by proposing a number of alternative measures of social capital namely corruption, ethnic tensions, contract intensive money and income inequality. These variables are previously shown by some studies to be a good proxy for trust-based social capital.

\footnotetext{
${ }^{2}$ The five waves of survey are for the period 1981-1984, 1989-1993, 1994-1999, 1999-2004, and 2005-2008. Number of countries in the first Wave is only 21 and it gradually increases to 69 in fourth Wave but drops to 57 in latest Wave.

${ }^{3}$ In our sample of 69 countries, only 34 countries are covered in at least one wave of survey, and there are only two countries surveyed in all waves. Since other data used in our study are in annual observation of 25 years, it is therefore not unexpected that the trust data would have a very severe problem of missing observations.
} 
For example, Baliamoune-Lutz (2009a) argues that corruption can be an alternative measure of trust as she investigates the effect of social capital (measured by level of corruption and ethnic tensions) on human well-being in the African countries. Although her study does not focus on the frequently-used measure of development i.e. economic growth, it is nonetheless able to show that corruption can be a good measure of (the lack of) trust.

This is based on the following three reasons: First, when corruption is present, people tend to trust public institutions less and they may also trust other people less and therefore less overall level of generalised trust ${ }^{4}$. Second, when generalised trust is strong, individuals are more willing to enter into economic transactions with individuals they do not necessarily know, and this creates competition for corruption practices. In other words, an individual having high degree of belief that there are strong contract enforcements and proper rules and regulations governing the transactions in place will definitely avoid any bribery activities since they believe that the transactions will be completed in due course and those who abuse one's confidence will definitely be punished. Therefore, this situation will significantly lower the returns from corruption (see also Bjørnskov \& Svendsen, 2003). Third, many studies have documented strong links between corruption and generalised trust and most of the studies find corruption causes (the lack of) trust, see for example Chang \& Chu (2006), Morris \& Klesner (2010), and Rothstein \& Uslaner (2005).

Ethnic tensions, which is a proxy for social cohesion, is also proposed as an essential ingredient in generating trust by Baliamoune-Lutz (2009a, 2009b); Easterly, Ritzen, \& Woolcock (2006); Ritzen, Easterly, \& Woolcock (2000). Ritzen et al. define social cohesion as "a state of affairs in which a group of people have an aptitude for collaboration that produces a climate for change." The arguments supporting the use of the ethnic tensions variable are that the degree of social cohesion often shapes the constraints towards policy reforms and determines the quality of institutions in developing countries. These in turn impact on whether and how pro-growth policies are devised and implemented. Government implementing reform needs confidence and patience from the public i.e. citizens have to trust the government that short term losses inevitably arising from reforms will be more than offset by long term gains. On the other hand, countries strongly divided along class and ethnic lines will place severe constraints on the attempts by politicians and interest groups to bring about policy reforms. Ethnic fractionalization could lead to civil war, promote high level of rent seeking activities, or cause social exclusion of specific ethnic groups, and these might give impacts to economic performance. In other words, ethnic fractionalization will cause a lack of social cohesiveness and increase the probability of negative actions and the risk of conflict or tensions (see Baliamoune-Lutz, 2009a, 2009b, and Easterly et al., 2006).

Contract intensive money (CIM) was originally proposed by Clague et al. (1999) as a measure of contract enforceability and secure property rights ${ }^{5}$. However, Baliamoune-Lutz (2011) argues that CIM can be a good measure of trust since it shares similar characteristics with generalised trust. According to Baliamoune-Lutz, CIM reflects the extent of generalized trust when an individual entering a transaction (i.e. holding money inside banks and the money will be used by the banks for various economic transactions like loan, investment, etc.) by trusting a large number of individuals not necessarily known to him, as well as trusting the capability of repayment since the individual enters the transaction in the present and receive income or collect payoffs in the future. Therefore, Baliamoune-Lutz argues that transactions involving CIM are trust-sensitive transactions.

\footnotetext{
${ }^{4}$ This is possible since the presence of corruption implies that people who gives bribes may receive more than what they would if their society is corruption-free. Corrupted people could be taking advantage over those who oppose it by receiving the services they are not entitled to and thus harm those who do not participate in the practice yet deservedly require the services.

${ }^{5}$ Clague et al. (1999) come to the conclusion that CIM is reflecting contract enforcement and secure property rights by using case studies investigating CIM fluctuations on the back of countries' drastic changes economically and politically, and by looking at its high and positive correlation with measures of governance (or institutional) quality such as political rights and institutional indicators from International Risk Country Guide (ICRG) and Business Environmental Risk Intelligence (BERI).
} 
She also shows CIM is actually a trust-sensitive transaction by looking at the variations in CIM data and its correlations with trust and other measures of social capital. To do this, she extracts a table showing data on trust and other measures of social capital from Knack \& Keefer $(1997)^{6}$ and augments the table with CIM data for three arbitrary periods ${ }^{7}$. She finds that CIM shares a similar characteristic with trust; they are both slow-changing. She also shows that CIM has statistically significant positive correlations with at least two measures of social capital from WVS i.e. trust and civic norms. She however acknowledges that the correlation between CIM and trust is much weaker in developing countries.

Table 1: Variations in the level of the generalized trust variable

\begin{tabular}{|c|c|c|c|c|c|c|}
\hline Country & $\begin{array}{c}\text { Wave I } \\
(1981- \\
1984)^{\mathrm{a}}\end{array}$ & $\begin{array}{c}\text { Wave II } \\
(1989- \\
1993)\end{array}$ & $\begin{array}{c}\text { Wave III } \\
\text { (1994- } \\
1998)\end{array}$ & $\begin{array}{c}\text { Wave IV } \\
(1999- \\
2004)\end{array}$ & $\begin{array}{c}\text { Wave V } \\
(2005- \\
2008)\end{array}$ & $\begin{array}{c}\text { Overall } \\
\text { change in } \\
\text { trust }^{\mathrm{b}}\end{array}$ \\
\hline Algeria & - & - & - & 11.2 & - & - \\
\hline Burkina Faso & - & - & - & - & 14.7 & - \\
\hline Ethiopia & - & - & - & - & 24.4 & - \\
\hline Ghana & - & - & - & - & 8.5 & - \\
\hline Mali & - & - & - & - & 17.5 & - \\
\hline Nigeria & - & 23.2 & 17.7 & 25.6 & - & 2.4 \\
\hline South Africa & - & 28.3 & 18.2 & 11.8 & 18.8 & -9.5 \\
\hline Uganda & - & - & - & 7.6 & - & - \\
\hline Zambia & - & - & - & - & 11.5 & - \\
\hline ZimbabI & - & - & - & 11.9 & - & - \\
\hline Bangladesh & - & - & 20.9 & 23.5 & - & 2.6 \\
\hline China & - & 60.3 & 52.3 & 54.5 & 52.3 & -8 \\
\hline Hong Kong & - & - & - & - & 41.1 & - \\
\hline India & - & 35.4 & 37.9 & 41 & 23.3 & -12.1 \\
\hline Indonesia & - & - & - & 51.6 & 42.5 & -9.1 \\
\hline Malaysia & - & - & - & - & 8.8 & - \\
\hline Pakistan & - & - & 20.6 & 30.8 & - & 10.2 \\
\hline Philippines & - & - & 5.5 & 8.4 & - & 2.9 \\
\hline Singapore & - & - & - & 16.9 & - & - \\
\hline South Korea & 38 & 34.2 & 30.3 & 27.3 & 28.2 & -9.8 \\
\hline Thailand & - & - & - & - & 41.5 & - \\
\hline Vietnam & - & - & - & 41.1 & 52.1 & 11 \\
\hline Argentina & 27 & 23.3 & 17.5 & 15.4 & 17.6 & -9.4 \\
\hline Brazil & - & 6.7 & 2.8 & - & 9.4 & 2.7 \\
\hline Chile & - & 22.7 & 21.9 & 22.8 & 12.6 & -10.1 \\
\hline Colombia & - & - & 10.4 & - & 14.5 & 4.1 \\
\hline Dominican Rep. & - & - & 26.4 & - & - & - \\
\hline El Salvador & - & - & - & 14.6 & - & - \\
\hline Guatemala & - & - & - & - & 15.7 & - \\
\hline
\end{tabular}

\footnotetext{
${ }^{6}$ The table is in page 1285 in Knack \& Keefer (1997) and it shows trust data for only one wave i.e. Wave II 1989-1993. Baliamoune-Lutz (2011) however does not update the table with a more recent data despite her study is more recent.

${ }^{7}$ Since the table from Knack \& Keefer (1997) is showing trust data for one wave only, Baliamoune-Lutz (2011) clusters the CIM data arbitrarily into three periods, the first is 11-14 years before the trust data are collected, the second is for the year after the survey, and the last is for the 7-8 years after the survey.
} 


\begin{tabular}{|l|ccccc|c|} 
Mexico & - & 33.5 & 31.2 & 21.3 & 15.6 & -17.9 \\
Peru & - & - & 5 & 10.7 & 6.3 & 1.3 \\
Trinidad and Tobago & - & - & - & - & 3.8 & - \\
Uruguay & - & - & 22.1 & - & 28.4 & 6.3 \\
Venezuela & - & - & 13.7 & 15.9 & - & 2.2 \\
\hline No. of observations & 2 & 9 & 17 & 20 & 23 & - \\
Average & 32.5 & 29.7 & 20.8 & 23.2 & 22.1 & -1.8 \\
\hline
\end{tabular}

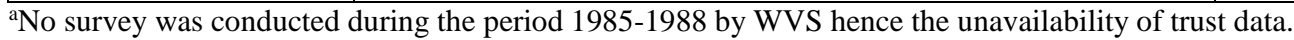

${ }^{b}$ We compute the overall change in trust by taking the difference between value of trust in latest wave and its value in the first available wave. Only 18 out of 34 countries have trust data in at least two waves to allow the computation of gain and loss in the overall level of trust in this countries.

We have replicated a similar exercise in our sample of 34 developing countries that have trust data. On the contrary, we find some variations in the trust data (albeit only 18 out of 34 countries in our sample have trust data for at least two waves to enable the computation of change in overall trust level. See Table 1 above). We also find the correlations between CIM and trust are statistically insignificant with mixed signs. Notwithstanding that, we still use CIM as one of the trust-alternative variables in our estimation because the results would therefore verify whether CIM is a suitable indicator of trust as proposed by Baliamoune-Lutz (2011), at least in term of its effect on growth and property rights, even though we find they are different in term of their characteristic (varying vs. non-varying characteristic).

For income inequality, we follow Zak \& Knack (2001) and Easterly et al. (2006). According to Zak and Knack, trust falls when there is wage discrimination in a country that is not based on economic factors. On the other hand, trust is higher when citizens in the country enjoy a fair and equitable income distribution. Easterly et al. also use income inequality as an indirect measure of social cohesion, whereas trust and membership variables (obtained from the WVS) as direct measures. They argue that socially cohesive countries will ensure the rich and poor alike share both the costs and benefits of reforms, and these countries will enjoy greater prosperity than more divided countries, where the benefits primarily go to the rich and the costs are borne by the poor. Therefore, a fair country in term of its income distribution often will have socially cohesive citizens with high trust level between the people.

\section{Theoretical framework, estimation strategy and data sources}

\section{Theoretical framework}

This paper seeks to investigate the impact of social capital on economic growth and to determine the possible channel of the impact. Social capital in this study is first proxied by generalized trust variable obtained from the WVS and subsequently by a number of alternative variables which have been shown to contain an element of trust.

To achieve this, a theoretical framework is specifically formulated as follows: Institutions are divided into three categories i.e. formal (or property rights) institutions, informal institutions (or social capital), and political institutions (political constraints) ${ }^{8}$. This proposition is developed from the literature of institutional theories specifically that of North $(1990 ; 2005)$ and Putnam (1993) - as previously discussed in literature section - and Acemoglu et al. (2005). Based on their frameworks, we

\footnotetext{
${ }^{8}$ Political institutions, though not the focus of our paper, are nevertheless included as control variable due to the increasing number of studies that advocate the supremacy of political institutions over other forms of institutions. These studies argue political institutions are actually the underlying reasons as to why different countries have different economic institutions, and eventually have different cross-country economic development. See for example Acemoglu et al. (2005), Stiglitz (2000), Rodrik \& Rosenzweig (2009), to name a few.
} 
define and measure property rights, social capital and political institutions, respectively. Intuitively, we postulate social capital and political institutions are the underlying determinants of the property rights institutions that matter for growth. In other words, social capital and political institutions are causing growth via the property rights channel ${ }^{9}$.

To test the inter-relationship between social capital, economic growth and property rights, two hypotheses are proposed:

First hypothesis: Institutions matter to economic growth in developing countries under study.

Second hypothesis: Social capital affects economic growth via the property rights channel.

The first hypothesis seeks to find evidence on the importance of institutions (proxied by property rights, social capital, and political institutions) to economic growth in the developing countries under study. Thus, the first hypothesis ought to be tested via a growth model and shall explain any growtheffect of the included institutional characteristics. Although all three institutional characteristics are included in this model, we retain the focus of this study on social capital parameter.

Specifically, by including social capital as one of the regressors in a growth model, and at the same time controlling for other steady state determinants of growth as well as other characteristics of institutions, we shall identify the social capital's direct impacts on growth. The findings therefore afford an appropriate comparison to previous studies that find positive relationship between social capital and growth.

The second hypothesis proposes that formal institutions, invariably proxied by a secure property rights environment, are determined by social capital and political institutions ${ }^{10}$. This hypothesis could be viewed as a strategy to unbundle the property rights institutions into two underlying components i.e. social capital and political institutions. Although this study is not the first to embark on this unbundling exercise, we view the previous studies ${ }^{11}$ that seek to unbundle institutions are only partially able to explain the characteristics of property rights institutions, and they do not account for deep determinants of institutions that are permanent and durable as suggested Glaeser, La Porta, Lopez-de-Silanes, \& Shleifer $(2004)^{12}$.

To test the above hypotheses, the following general equations are proposed:

$$
\begin{aligned}
& g_{i t}=\beta_{0}+\beta_{1} \ln y_{i t-1}+\beta_{2} p r_{i t-1}+\beta_{2} s c_{i t-1}+\beta_{2} \operatorname{pol}_{i t-1}+\beta_{3} X_{i t}^{\prime}+\eta_{i}+\varepsilon_{i t} \\
& p r_{i t}=\beta_{0}+\beta_{1} s c_{i t-1}+\beta_{2} p_{i t-1}+\beta_{3} X_{i t-1}^{\prime}+\eta_{i}+\varepsilon_{i t}
\end{aligned}
$$

\footnotetext{
${ }^{9}$ Notwithstanding that, it is reasonable to expect social capital and political institutions would have possibly caused economic growth via a channel other than property rights. This is particularly feasible in developing countries where formal institutions are somewhat lacking yet the countries' economies would still somehow grow. Recall that Rodrik (2008), by introducing the term "second-best" institutions, argues the so called first-best property rights institutions (as those adopted by developed and industrial countries) might not succeed to reduce costs and promote growths when they are implemented in developing countries.

${ }^{10}$ Although we exclude "political institutions" word from the second hypothesis since the parameter of interest is social capital, we nevertheless include political institutions index in the estimation to control for its effect which would otherwise be picked up by other variables in the model.

${ }_{11}$ Previously, Acemoglu \& Johnson (2005) unbundle institutions in two i.e. property rights institutions and contracting institutions, while Rodrik (2005) unbundle institutions into four components namely market-creating, market stabilizing, market-regulating and market-legitimizing institutions.

${ }^{12}$ Nevertheless, Glaeser et al. (2004) discuss the permanent and durable deep determinants from the perspective of political constraints only i.e. constitutional rules that are designed to constraint government. They however completely omit the private constraints mechanisms from the perspective of informal institutions as proposed by North (2005) -in other words, social capital.
} 
In the above equations, $g_{i t}=\Delta \ln g y_{i t}$ is real GDP per capita growth rates, $\beta_{0}$ is a constant term, $\ln y_{i t-1}$ is lagged income or natural logarithm of real GDP per capita in the previous period, $p r_{i t-1}$, $s c_{i t-1}$, and $p o l_{i t-1}$ are the index of property rights institutions, social capital variable and the index of political institutions, respectively, and they are one-period lagged. $X$ is a vector of control variables, $\varepsilon_{i t} \sim N\left(0, \sigma^{2} I\right)$ is an i.i.d. error term, and $\eta_{i}$ is time-invariant country-specific effect term ${ }^{13}$.

In Equation (1), we add a set of control variables or steady state determinants, $X$, namely stock of physical $(s k)$ and human $(s h)$ capitals, $(n+g+\delta)$ term that accounts for the sum of population growth, growth in exogenous technological process, and depreciation rate, respectively.

In Equation (2), we follow Williamson \& Kerekes (2011) to include the following control variables: real GDP per capita growth, education attainment (measured by secondary school attainment for population age 15 and above), government consumption (as a percentage of total GDP) and urban population (as a percentage of total population) as these set of controls variables has been shown to have significant effects on institutional quality measured by property rights. Thus, the inclusion of these control variables precludes social capital and political institutions from picking up the effects these control variables have on the property rights. In other words, once these variables are controlled for, the estimated coefficients for social capital and political institutions will truly reflect their influence on property rights.

\section{Estimation strategy}

In this study, we employ fixed effect estimation technique since the method is capable of reducing omitted variable bias and time-invariant heterogeneity compared to the commonly used cross sectional estimation ${ }^{14}$.

The estimation comprises of two stages. In the first stage, we begin with a growth model (Equation 1) which includes all three institutional variables to test for their direct impact on economic growth for our sample of 69 developing countries, controlling for the usual steady-state growth determinants. The growth model of Equation (1) reveals a potential endogeneity problem. Firstly, because of the presence of a lagged dependent variable, and secondly institutional variables could be endogenous since reverse causation from growth to institutions is possible. While an endogenous lagged dependent variable is not much of a worry since the focus of this study is on institutions, endogenous institutional variables are tackled by lagging them by a period in all models they enter to prevent reverse causation.

Besides, if it is true that social capital and political institutions do cause property rights, including the three of them as regressors in a regression would have probably caused multicollinearity problem and, though the estimators remain unbiased, standard errors of the estimators will tend to be large and this will eventually affect the parameters' significance.

However, the main objective to include all three institutional variables in a growth model is to determine their direct impacts towards growth. While property rights' direct impact on growth is somewhat expected, the estimation could also uncover any possibility of social capital's and political

\footnotetext{
${ }^{13}$ A closer look at the Equation (1) and (2) reveal that simultaneous equations estimation is not possible even though both equations apparently have the similar explanatory variables. The explanatory variables are included in Equation 2 as lagged variables, i.e. social capital $\left(s c_{i t-1}\right)$ and political institutions $\left(\right.$ pol $\left._{i t-1}\right)$ are lagged by one-period in the Equation (2) to determine the current value of property rights $\left(p r_{i t}\right)$. When property rights, social capital and political institutions variables appear in Equation (1) as lagged variables, effectively they are different from the variables that appear in Equation (2) due to difference in lags i.e. $p r_{i t}$ is different from $p_{i t-1}$.

${ }^{14}$ Hausman tests statistics which indicate fixed effect is preferable to random effect is available upon request.
} 
institutions' direct impact on growth and this could be an interesting finding for comparison against their indirect impacts in the second hypothesis. To mitigate this issue, the three institutional variables are included in the growth models in multiple combinations and related assumptions are specified.

In the second stage, we intend to identify the robustness of trust effect on growth when we assumed social capital influence growth indirectly via property rights channel. We repeat the growth estimation (Equation 1) with only trust and political institutions, in addition to the steady state growth determinants, and we omit property rights variable.

In the second model i.e. the property rights model (Equation 2), we seek to confirm the property rights channel through which the effects of social capital run towards growth. In other words, this model would illustrate the channel and the size of social capital's indirect effects on the economic performance in developing countries. Furthermore, the model also enables us to show the underlying determinants of property rights (formal institutions). All explanatory variables in the property rights regressions are also lagged by one-period to mitigate endogeneity problem. We acknowledge the possible multicollinearity problem between the control variables in the second model such as GDP per capita growth, education attainment, government consumption but retain the focus on social capital effect on property rights.

The variable of interest in this study is social capital. We first use generalized trust data obtained from the WVS to measure social capital and by using trust data, an appropriate comparison can be made to the findings of previous trust-based social capital studies. Furthermore, since trust has been widely used in previous cross-sectional studies of social capital, this study could be an avenue to investigate the robustness WVS's trust data when they are used in panel analysis.

Finally, to investigate the robustness of trust-alternative variables, we repeat both estimations of growth model (Equation 1) and property rights model (Equation 2), with the proposed trust-alternative variables replacing generalized trust variable. We estimate trust-alternative variables' effects on growth without and with the presence of political institutions index, at the same time controlling for the control variables as previously discussed.

\section{Data sources}

A panel for 69 developing countries from three regions, Africa, East Asia, and Latin America for a period of 25 years beginning from 1984 to 2008 is used in this study. Data on real GDP percapita and population growth are obtained from World Development Indicators (WDI) provided by the World Bank (2009). We follow Mankiw, Romer, \& Weil (1992) in assuming exogenous technological change plus depreciation rate equal to 0.05 , and in using investment share of real per capita GDP as a proxy for physical capital and the data is obtained from Heston, Summers, \& Aten (2009). To proxy for human capital, we follow Ahmad \& Hall (2012) to use secondary school attainment for population age 15 and above based on Barro \& Lee (2010) educational data that are converted in annual form.

To measure the property rights institutions and political institutions, we utilize the identical indices used in Ahmad and Hall (2012). Precisely, there are two indices, the first is a simple average of four indicators from International Country Risk Guide (ICRG) obtained from the PRS Group (2009) which reflects security of property right, and the second is a simple average of four political indicators obtained from four different sources to reflect the political institutions.

The four institutional indicators from ICRG are i.e. Investment Profile, Law and Order, Bureaucracy Quality, and Government Stability and they are used to reflect security of property rights. Meanwhile, the four indicators to proxy for political institutions are Polity 2 from Polity IV data (Marshall \& Jaggers, 2008), Political rights from Freedom in the World index which is also known as Gastil index 
(Gastil, 1978), Polcon3 from The Political Constraint Index (POLCON) Dataset (Henisz, 2010) and Checks from Database of Political Institutions by the World Bank (Beck, Clarke, Groff, Keefer, \& Walsh, 2001) -see Table A in the appendix for detailed explanation of each of these variables.

Generalized trust data used to measure social capital are obtained from the World Values Survey, or WVS, (2009). The measure of trust is obtained by taking the percentage of respondents who choose the answer "Most people can be trusted" to the survey question "Generally speaking, would you say that most people can be trusted or that you need to be very careful when dealing with people?". The observations are drawn from Wave II (1989-1993) to Wave V (2005-2008) ${ }^{15}$. Only 34 out of 69 countries in our sample are surveyed during the four waves.

The data for trust-alternative variables are obtained from various sources. Both corruption and ethnic tensions indicators are obtained from the International Country Risk Guide (ICRG) provided by the PRS Group (2009). Contract intensive money as defined by Clague et al. (1999) is the ratio of noncurrency money to the total money supply, or (M2-C)/M2 where M2 is broad definition of money supply and C is currency held outside banks. Data on M2 and C are obtained from Datastream and World Development Indicator (WDI) of the World Bank (2009). To proxy for income inequality, Gini index, also obtained from WDI, is used, following Easterly et al. (2006) and Rodrik (1999) -see Table A in the appendix for detailed explanation of each of these variables.

Table 2 below presents the correlation coefficients for the variables used in this study. The correlation between GDP per capita growth and institutional indicators (property rights, generalized trust and political institutions) are apparently in line with the fundamental. However, insignificant correlations between generalized trust and its alternative measures are observed, but they are thought of as the outcome of the limited number of trust data that prevents any meaningful correlations.

Table 2: Spearman rank correlation coefficients

\begin{tabular}{|c|c|c|c|c|c|c|c|}
\hline Variables & $\begin{array}{l}\text { Real GDP } \\
\text { per capita } \\
\text { growth }\end{array}$ & $\begin{array}{l}\text { Property } \\
\text { rights } \\
\text { index }\end{array}$ & $\begin{array}{l}\text { Political } \\
\text { institutions } \\
\text { index }\end{array}$ & $\begin{array}{l}\text { Genera- } \\
\text { lized } \\
\text { trust }\end{array}$ & $\begin{array}{l}\text { Corrup- } \\
\text { tion }\end{array}$ & $\begin{array}{l}\text { Ethnic } \\
\text { tensions }\end{array}$ & $\begin{array}{c}\text { Contract } \\
\text { intensive } \\
\text { money }\end{array}$ \\
\hline $\begin{array}{l}\text { Property rights } \\
\text { index }\end{array}$ & $\begin{array}{c}0.307 * * * \\
(1696)\end{array}$ & & & & & & \\
\hline $\begin{array}{l}\text { Political } \\
\text { institutions index }\end{array}$ & $\begin{array}{c}0.121 * * * \\
(1709)\end{array}$ & $\begin{array}{c}0.286^{* * * *} \\
(1706) \\
\end{array}$ & & & & & \\
\hline Generalized trust & $\begin{array}{c}0.386^{* * *} \\
(71)\end{array}$ & $\begin{array}{c}0.033 \\
(71)\end{array}$ & $\begin{array}{c}-0.336^{* * * *} \\
(71)\end{array}$ & & & & \\
\hline Corruption & $\begin{array}{l}0.044^{*} \\
(1696)\end{array}$ & $\begin{array}{c}0.285^{* * * *} \\
(1706)\end{array}$ & $\begin{array}{c}0.132 * * * \\
(1706)\end{array}$ & $\begin{array}{c}0.024 \\
(71)\end{array}$ & & & \\
\hline Ethnic tensions & $\begin{array}{c}0.157 * * * \\
(1697)\end{array}$ & $\begin{array}{c}0.377 * * * \\
(1706)\end{array}$ & $\begin{array}{c}0.268 * * * \\
(1707)\end{array}$ & $\begin{array}{c}-0.06 \\
(71)\end{array}$ & $\begin{array}{c}0.237 * * * \\
(1706)\end{array}$ & & \\
\hline $\begin{array}{l}\text { Contract intensive } \\
\text { money }\end{array}$ & $\begin{array}{c}0.230 * * * \\
(1578)\end{array}$ & $\begin{array}{c}0.507 * * * \\
(1571)\end{array}$ & $\begin{array}{c}0.496 * * * \\
(1580)\end{array}$ & $\begin{array}{c}-0.121 \\
(68)\end{array}$ & $\begin{array}{c}0.231 * * * \\
(1571)\end{array}$ & $\begin{array}{c}0.357 * * * \\
(1571)\end{array}$ & \\
\hline Income inequality & $\begin{array}{c}-0.128 * * \\
(330)\end{array}$ & $\begin{array}{l}0.056 \\
(330)\end{array}$ & $\begin{array}{c}0.364 * * * \\
(330)\end{array}$ & $\begin{array}{c}-0.197 \\
(17)\end{array}$ & $\begin{array}{c}0.141 * * \\
(330)\end{array}$ & $\begin{array}{c}0.283 * * * \\
(330)\end{array}$ & $\begin{array}{c}0.433 * * * \\
(311)\end{array}$ \\
\hline
\end{tabular}

\section{Estimation results and discussion}

First stage: growth estimation augmented with institutional variables to identify individual direct effect

\footnotetext{
${ }^{15}$ We omit trust data obtained from Wave I (1981-1984) from our regressions since there were only two countries from our 69-country sample surveyed in the first wave. Furthermore, there is a gap in the data between 1985-1988 since there was no survey during the period.
} 
For this stage, we estimate the growth model (Equation 1) with all three institutional variables: generalized trust, property rights index and political institutions index to test for their individual significance on growth. Conditional convergence parameter and the standard steady state determinants are also included. Table 3 below presents the results.

In regression (1) to (3), the three institutional variables are included individually respectively to test their individual direct effect on growth. Property rights and political institutions indices are found to be significant at the 5\% level but generalized trust is not. For regression (4) and (5), a specific assumption needs to be made regarding the omission of property rights variable (in model 4) and as well as trust's channel of effect (in model 5) ${ }^{16}$. Assuming social capital and political institutions could have their effects operating via the property rights channel, property rights index is therefore omitted in regression (4). However, neither social capital nor political institutions is significant despite the political variable's significance when it is included individually (in regression 2). In regression (5), we suppose trust causes growth via a channel other than property rights (perhaps via a political institutions channel -hence the variable's omission- or other possible channels), thus we include property rights index and trust in the regression. Similarly, both are not significant despite the property rights' significance when it is included individually (in regression 1). The result of institutional nonsignificance stands when all three institutional variables are included in the general model (model 6).

Table 3: Fixed effect regression of growth model to test for institutional variables' direct effect

Dependent variable: Log real GDP percapita growth

\begin{tabular}{|c|c|c|c|c|c|c|c|}
\hline Estimation model & (1) & (2) & (3) & (4) & (5) & (6) & (7) \\
\hline Lagged income & $\begin{array}{l}-0.05 * * * \\
(0.015)\end{array}$ & $\begin{array}{l}-0.05 * * * \\
(0.014)\end{array}$ & $\begin{array}{l}-0.075^{* *} \\
(0.032)\end{array}$ & $\begin{array}{l}-0.076^{* *} \\
(0.031)\end{array}$ & $\begin{array}{l}-0.065 \\
(0.064)\end{array}$ & $\begin{array}{l}-0.067 \\
(0.068)\end{array}$ & $\begin{array}{l}-0.05 * * * \\
(0.015)\end{array}$ \\
\hline Physical capital & $\begin{array}{l}0.032 * * * \\
(0.006)\end{array}$ & $\begin{array}{l}0.033 * * * \\
(0.006)\end{array}$ & $\begin{array}{l}0.123^{* * * *} \\
(0.036)\end{array}$ & $\begin{array}{l}0.121 * * * \\
(0.039)\end{array}$ & $\begin{array}{l}0.122 * * * \\
(0.039)\end{array}$ & $\begin{array}{l}0.121 * * * \\
(0.040)\end{array}$ & $\begin{array}{l}0.032 * * * \\
(0.006)\end{array}$ \\
\hline Population growth & $\begin{array}{l}0.024 * * * \\
(0.007)\end{array}$ & $\begin{array}{l}0.024 * * * \\
(0.007)\end{array}$ & $\begin{array}{l}-0.023 \\
(0.024)\end{array}$ & $\begin{array}{l}-0.023 \\
(0.024)\end{array}$ & $\begin{array}{l}-0.024 \\
(0.026)\end{array}$ & $\begin{array}{l}-0.024 \\
(0.025)\end{array}$ & $\begin{array}{l}0.024 * * * \\
(0.007)\end{array}$ \\
\hline Human capital & $\begin{array}{l}0.002 * * * \\
(0.000)\end{array}$ & $\begin{array}{l}0.002 * * * \\
(0.001)\end{array}$ & $\begin{array}{l}0.002 \\
(0.001)\end{array}$ & $\begin{array}{l}0.002 \\
(0.002)\end{array}$ & $\begin{array}{l}0.002^{*} \\
(0.001)\end{array}$ & $\begin{array}{l}0.002 \\
(0.001)\end{array}$ & $\begin{array}{l}0.002 * * * \\
(0.001)\end{array}$ \\
\hline Property rights index & $\begin{array}{l}\mathbf{0 . 0 0 4} * * \\
(0.002)\end{array}$ & & & & $\begin{array}{l}-0.004 \\
(0.017)\end{array}$ & $\begin{array}{l}-0.003 \\
(0.018)\end{array}$ & $\begin{array}{l}\mathbf{0 . 0 0 4} * * \\
(0.002)\end{array}$ \\
\hline $\begin{array}{l}\text { Political institutions } \\
\text { Index }\end{array}$ & & $\begin{array}{l}\mathbf{0 . 0 0 2} * * \\
(0.001)\end{array}$ & & $\begin{array}{l}-0.001 \\
(0.005)\end{array}$ & & $\begin{array}{l}-0.001 \\
(0.006)\end{array}$ & $\begin{array}{l}0.002 \\
(0.001)\end{array}$ \\
\hline Generalized trust & & & $\begin{array}{l}0.001 \\
(0.001)\end{array}$ & $\begin{array}{l}0.001 \\
(0.001)\end{array}$ & $\begin{array}{l}0.001 \\
(0.001)\end{array}$ & $\begin{array}{l}0.001 \\
(0.001)\end{array}$ & \\
\hline Constant & $\begin{array}{l}0.007 \\
(0.082)\end{array}$ & $\begin{array}{l}-0.029 \\
(0.075)\end{array}$ & $\begin{array}{l}0.282 \\
(0.296)\end{array}$ & $\begin{array}{l}0.311 \\
(0.268)\end{array}$ & $\begin{array}{l}0.241 \\
(0.364)\end{array}$ & $\begin{array}{l}0.263 \\
(0.388)\end{array}$ & $\begin{array}{l}0.002 \\
(0.082)\end{array}$ \\
\hline Observations & 1,404 & 1,413 & 59 & 59 & 59 & 59 & 1,404 \\
\hline Number of country & 62 & 62 & 27 & 27 & 27 & 27 & 62 \\
\hline Adj. R-squared & 0.297 & 0.291 & 0.284 & 0.258 & 0.260 & 0.231 & 0.297 \\
\hline
\end{tabular}

The main reason for the weak regression results is apparently the limited number of trust observations. A quick look at number of observation in the estimations shows that it drops significantly whenever the trust variable is included. To support this argument, we exclude the trust variable in regression (7) and estimate the growth model with property rights and political institutions only (of course with the assumption that the political variable is affecting growth not via property rights channel). Only property rights index emerges significant at the 5\% level and the number of observations increases significantly (to 1404).

${ }^{16}$ Without this assumption, omitting the variables would definitely cause omitted variable bias in the estimations. 
The above exercise yields two important findings. Firstly trust data indeed suffer a severe missing observation problem and therefore estimations involving the trust variable in annual panel setting produce highly unrobust results. Secondly, a possible indication could be drawn from the results in regression (2) and (7) -when political variables are significant in the individual regression, but not when it is regressed with property rights -regarding the channel of political institutions' growth-effect, which is probably via the property rights channel. However, it is still too early to make a definitive conclusion that the effect of political institutions towards growth is via property rights channel. We expect a more conclusive finding about the channel of impact is available when the property rights estimation (Equation (2) is done in the next stage.

\section{Second stage: A. using generalized trust in growth and property right estimations to identify the social capital's channel of effect}

In this second stage, we first use generalized trust data to proxy for social capital. Our focus now is to test for the robustness of trust's impact on growth and property rights, based on the Equation (1) and (2) respectively. Since we hypothesize that trust cause growth via property rights channel, property rights index is therefore omitted in Equation (1). Subsequently in Equation (2) we seek to support the hypothesis by testing trust significance on property rights. In both occasions, we test the significance of trust with and without the presence of the political institutions variable. The ultimate aim of this exercise therefore would indicate the robustness of trust data obtained from the WVS when estimated in a panel setting. This is of particular importance since the majority of studies on social capital that use trust data (typically obtained from the WVS which in turn have missing observation problem) are cross-sectional.

Table 4 below shows the results of Pooled $\mathrm{OLS}^{17}$ and fixed effect estimations of growth model augmented with the trust variable. In regressions (8) and (9), we assume that generalized trust has enough variations so that its effect can be captured when the variable is included in the estimation. Both models however yield insignificant coefficients for generalized trust variable.

Next, the assumption about the variations in trust data is eliminated. Consistent with the majority of previous studies on trust, now we assume trust is constant, and the effect of the trust variable will therefore be captured via the $\eta_{i}$ term i.e. a term to represents the time-constant unobserved country specific effects. We run pooled OLS regressions in (10) and (11) and compare them with fixed effect regressions in (12) and (13). In pooled OLS regressions, generalized trust turns out to be insignificant. Again, we suspect limited trust data is the culprit. Suppose that the trust variable is significant in pooled OLS, and looking at F-test for the null hypothesis of $\eta_{i}$ equal to zero that is strongly rejected in fixed effects regressions (model 12 and 13), we may conclude that it is highly likely that trust is actually the underlying unobserved heterogeneity factor between the countries under studies. Furthermore, the test statistics for F-test in regressions (8) and (9), when the trust variable is included, fail to reject the null that $\eta_{i}$ is equal to zero. To support our case that limited trust data is ruining the regression results, in regression (13) the political institutions index is now significant at 5\% even though it is not in regression (9) earlier, and also note the number of observation now soars to 1413 from 59.

We replicate the estimation strategy in Table 4, but now the dependent variable is the property rights. Similar assumptions about generalized trust hold, and a number of control variables i.e. real GDP per capita growth, education attainment, government consumption and urban population are included. Table 5 below presents the results which are similar to Table 4. The only exception is that test

\footnotetext{
${ }^{17}$ The reason we report pooled OLS estimation results despite fixed effect is the preferred method, is that it is for comparison purpose to the previous social capital studies majority of which use cross sectional estimation.
} 
statistics of F-test in regression (14) and (15) remains significant at least at 5\% thus rejecting the null hypothesis of $\eta_{i}=0$, and similarly there is significant F-test of $\eta_{i}=0$ in regression (18) and (19). Since trust is assumed to be varying in regression (14) and (15) but constant in (18) and (19), significant $\eta_{i}$ term in both occasions therefore is believed to have captured non-trust unobserved heterogeneity factor (i.e. the time-invariant country specific effect).

Table 4: Robustness test for the generalized trust data in growth estimation

\begin{tabular}{|c|c|c|c|c|c|c|}
\hline \multicolumn{7}{|c|}{ Dependent variable: Log real GDP percapita growth } \\
\hline \multirow{2}{*}{ Estimation model } & \multicolumn{2}{|c|}{ Fixed effects ${ }^{\mathrm{a}}$} & \multicolumn{2}{|c|}{ Pooled OLS } & \multicolumn{2}{|c|}{ Fixed effects ${ }^{\mathrm{b}}$} \\
\hline & $(8)$ & (9) & $(10)$ & $(11)$ & $(12)$ & $(13)$ \\
\hline \multirow[t]{2}{*}{ Lagged income } & $-0.075 * *$ & $-0.076^{* *}$ & -0.006 & -0.005 & $-0.042 * * *$ & $-0.042 * * *$ \\
\hline & $(0.032)$ & $(0.031)$ & $(0.006)$ & $(0.006)$ & $(0.014)$ & $(0.014)$ \\
\hline \multirow[t]{2}{*}{ Physical capital } & $0.123 * * *$ & $0.121 * * *$ & $0.043 * * *$ & $0.043 * * *$ & $0.035^{* * *}$ & $0.033 * * *$ \\
\hline & $(0.036)$ & $(0.039)$ & $(0.014)$ & $(0.014)$ & $(0.006)$ & $(0.006)$ \\
\hline \multirow[t]{2}{*}{ Population growth } & -0.023 & -0.023 & -0.000 & 0.000 & $0.023 * * *$ & $0.024 * * *$ \\
\hline & $(0.024)$ & $(0.024)$ & $(0.006)$ & $(0.006)$ & $(0.007)$ & $(0.007)$ \\
\hline \multirow[t]{2}{*}{ Human capital } & 0.002 & 0.002 & 0.000 & 0.000 & $0.003 * * *$ & $0.002 * * *$ \\
\hline & $(0.001)$ & $(0.002)$ & $(0.000)$ & $(0.000)$ & $(0.001)$ & $(0.001)$ \\
\hline \multicolumn{2}{|l|}{ Political institutions } & -0.001 & & -0.001 & & $0.002 * *$ \\
\hline \multicolumn{2}{|l|}{ Index } & $(0.005)$ & & $(0.002)$ & & $(0.001)$ \\
\hline \multirow{2}{*}{ Generalized trust } & 0.001 & 0.001 & 0.000 & 0.000 & & \\
\hline & $(0.001)$ & $(0.001)$ & $(0.000)$ & $(0.000)$ & & \\
\hline \multirow[t]{2}{*}{ Constant } & 0.282 & 0.311 & -0.068 & -0.066 & -0.023 & -0.029 \\
\hline & $(0.296)$ & $(0.268)$ & $(0.070)$ & $(0.072)$ & $(0.075)$ & $(0.075)$ \\
\hline Observations & 59 & 59 & 59 & 59 & 1,418 & 1,413 \\
\hline Number of country & 27 & 27 & & & 62 & 62 \\
\hline Adj. R-squared & 0.284 & 0.258 & 0.280 & 0.269 & 0.287 & 0.291 \\
\hline F-test $\eta_{i}=\mathbf{0}$ & 1.01 & 0.97 & & & 6.56 & 6.51 \\
\hline p-value & 0.486 & 0.532 & & & 0.000 & 0.000 \\
\hline \multicolumn{7}{|c|}{$\begin{array}{l}\text { Note: Robust standard errors are in parentheses. } * * *, * *, * \text { indicate the coefficient is significant at } 1 \%, 5 \% \text { and } 10 \% \\
\text { respectively. }\end{array}$} \\
\hline
\end{tabular}

Table 5: Robustness test for the generalized trust data in property rights estimation

\begin{tabular}{|c|c|c|c|c|c|c|}
\hline \multicolumn{7}{|c|}{ Dependent variable: Property rights index } \\
\hline \multirow{2}{*}{ Estimation model } & \multicolumn{2}{|c|}{ Fixed effects ${ }^{a}$} & \multicolumn{2}{|c|}{ Pooled OLS } & \multicolumn{2}{|c|}{ Fixed effects ${ }^{\mathrm{b}}$} \\
\hline & $(14)$ & $(15)$ & $(16)$ & $(17)$ & $(18)$ & $(19)$ \\
\hline Political institutions & & -0.012 & & -0.055 & & $\mathbf{0 . 1 3 8} * * *$ \\
\hline Index & & $(0.120)$ & & $(0.101)$ & & $(0.022)$ \\
\hline Generalized trust & $\begin{array}{l}-0.036 \\
(0.025)\end{array}$ & $\begin{array}{l}-0.037 \\
(0.031)\end{array}$ & $\begin{array}{l}-0.001 \\
(0.009)\end{array}$ & $\begin{array}{l}-0.005 \\
(0.013)\end{array}$ & & \\
\hline Real GDP per capita & 2.207 & 2.225 & 8.410 & 8.570 & $3.620 * * *$ & $3.334 * * *$ \\
\hline Growth & $(5.849)$ & $(5.988)$ & $(5.647)$ & $(5.830)$ & $(0.594)$ & $(0.597)$ \\
\hline Education & -0.025 & -0.024 & 0.019 & 0.018 & $0.013 * *$ & $0.013 * *$ \\
\hline attainment & $(0.035)$ & $(0.038)$ & $(0.011)$ & $(0.011)$ & $(0.006)$ & $(0.006)$ \\
\hline Government & 0.075 & 0.076 & -0.031 & -0.035 & -0.011 & -0.009 \\
\hline consumption & $(0.068)$ & $(0.069)$ & $(0.029)$ & $(0.029)$ & $(0.008)$ & $(0.008)$ \\
\hline Urban population & 0.111 & 0.110 & $0.013 * *$ & $0.014 * *$ & $0.107 * * *$ & $0.094 * * *$ \\
\hline & $(0.071)$ & $(0.076)$ & $(0.007)$ & $(0.007)$ & $(0.008)$ & $(0.008)$ \\
\hline Constant & 0.329 & 0.464 & $4.890 * * *$ & $5.262 * * *$ & -0.015 & -0.058 \\
\hline & $(3.967)$ & $(4.550)$ & $(0.503)$ & $(0.848)$ & $(0.351)$ & $(0.343)$ \\
\hline
\end{tabular}




\begin{tabular}{lllllll}
\hline Observations & 64 & 64 & 64 & 64 & 1,441 & 1,441 \\
Number of country & 31 & 31 & & & 62 & 62 \\
Adj. R-squared & 0.553 & 0.537 & 0.230 & 0.224 & 0.617 & 0.629 \\
F-test $\eta_{i}=\mathbf{0}$ & $\mathbf{2 . 4 0}$ & $\mathbf{2 . 2 8}$ & & & $\mathbf{2 1 . 9 2}$ & $\mathbf{2 3 . 1 9}$ \\
p-value & $\mathbf{0 . 0 1 1}$ & $\mathbf{0 . 0 1 7}$ & & & $\mathbf{0 . 0 0 0}$ & $\mathbf{0 . 0 0 0}$ \\
\hline
\end{tabular}

Note: Robust standard errors are in parentheses. ***,**,* indicate the coefficient is significant at $1 \%, 5 \%$ and $10 \%$ respectively.

a, ${ }^{\mathrm{b}}$ Refer notes in Table 2 above.

Since this model uses property rights as dependent variable in panel estimation, this finding is particularly interesting. It is highly likely that the possible candidates for the underlying unobserved time-constant country heterogeneity are none other than the widely used instrument variables in the previous cross-sectional institutional studies, for example: ethno-linguistic fractionalization (Easterly, 2006; Mauro, 1995), settler's mortality (Acemoglu, Johnson, \& Robinson, 2001; (Rodrik, Subramaniam, \& Trebbi, 2004), and distance from equator and fraction of population that speaks English/European language (R. E. Hall \& Jones, 1999).

Recall these instruments have been used for endogenous institutional variables and are shown to be good predictors in numerous cross-country income and growth estimations. They are however persistent over time and this characteristic apparently makes them the best candidates to be captured in the country fixed effect term in panel analysis.

Another interesting finding from Table 5 is that we obtain somewhat greater coefficient and higher significance level for the political institutions variable i.e. 0.138 and $1 \%$ level in the property rights estimation (see model 19) than in growth estimation (Table 4 model 13) with 0.002 at $5 \%$ level. Therefore, this finding undoubtedly give credibility to the result in model (2) and (7) in Table 1 earlier which indicates political institutions do cause growth and the causation mostly run indirectly via the property rights channel. Furthermore, this finding is also in line with Acemoglu et al. (2005)'s theory of political prominence in determining economic (or formal) institutions that matter for growth.

\section{Second stage: B. using trust-alternative variables in growth and property right estimations to identify the social capital's channel of effect}

Once we find that the generalized trust data from the WVS suffer missing observations problem hindering any meaningful impact on growth and property rights, we now replace trust with the proposed alternative variables.

First, we re-estimate the growth model (Equation 1) augmented with each of the four trust-alternative variables (models 20-23), and then a general model (model 24) with the presence of all four variables. In the final model (25), we augment the growth estimation with the significant trust-alternative variables only, found in preceding regressions. We repeat these steps in the estimation of model (26) until (31), with the presence of the political institutions.

The results in Table 6 show that social capital (measured corruption and ethnic tensions) indeed matter for growth. The significance of social capital continues even when we control for political institutions. Corruption is consistently statistically significant at 5-10\% level with coefficients ranging from 0.002 to 0.005 in any estimation whenever it is present. The sign of corruption's coefficients, however, turns out to be negative although it is expected to be positive ${ }^{18}$.

\footnotetext{
${ }^{18}$ Recall corruption data used in this study is based on the corruption ranking given to the countries in the sample. Least corrupted countries will receive higher score in the corruption ranking, hence the expected positive coefficient against growth.
} 
In hindsight, one would think that a lower level of corruption would lead to efficient business exchanges, less threat to foreign investments and a situation where the general public have more confidence in the government to carry out reform programs. These in turn would translate into higher generalized trust level in the country and eventually better economic performance. Our results, despite confirming the fact that corruption matters for growth, find that higher corruption level in the developing countries under study is actually causing their economic growth. We will discuss further the possible reason behind corruption's positive growth-effect in the next sub-section.

The other significant variable is ethnic tensions. It is statistically significantly different from zero at 1$5 \%$ level, either when it enters the estimation individually or in the growth model augmented with significant variables (model 25 and 31). The ethnic tensions variable however is insignificant in the general model where all measures of social capital are present (model 24 and 30). Note the drastic drop in number of observations in the regressions that include income inequality, and arguably this is the reason causing these conflicting results, (i.e. on the significance and sign of the ethnic tensions coefficients in the estimation of the general model (model 24 and 30), and estimation with only significant variables (model 25 and 31)). Nevertheless, the ethnic tensions variable has the expected positive sign whenever it is significant ${ }^{19}$. Our results therefore confirm the findings of a positive growth-effect of social cohesion, measured by the ethnic tensions variable, by Baliamoune-Lutz (2009a, 2009b); Easterly et al. (2006); and Ritzen et al. (2000).

It is also interesting to note that contract intensive money (CIM) is insignificant notwithstanding the sufficiently large number of observations in estimations involving the variable (see model 22 and 28). This result is apparently in contrast to Baliamoune-Lutz (2011) who uses CIM to reflect trust, and Clague et al. (1999) who uses CIM to reflect contract enforceability and secure property rights, and they both find CIM matters for growth. And since we mention earlier that this study follows Baliamoune-Lutz (2011) in using CIM as a proxy for trust, it is fair to infer that CIM is indeed not a robust trust-substitute (in term of characteristic and growth-effect). Therefore, as far as this study is concerned, the arguments by Baliamoune-Lutz (2011) about the similar characteristics between trust and CIM can be rejected.

In spite of CIM's insignificance, however, we are not in a haste to prejudge a similar rejection to Clague et al.'s proposition that CIM is a good proxy for contract enforceability and secure property rights. We leave this proposition until property rights estimation (Equation 2) is done next, in which we empirically test their relationship ${ }^{20}$.

The political institutions index is consistently statistically different from zero at 5\% level in regressions where the included social capital variable is significant too (i.e. when corruption and ethnic tensions enter model (26) and (27), respectively). Similarly, it remains significant in the general regression when both significant social capital variables are present (model 31). The index however becomes insignificant in regression with CIM and income inequality, and also in regressions where all social capital variables are present.

The findings in model (25) and (31), where social capital (the informal constraints) are able to significantly predict growth with and without the presence of political institutions variable, therefore strengthen North (2005)'s argument on the primacy of mental model concept that reflects the informal rules and constraints over political constraints ${ }^{21}$.

\footnotetext{
${ }^{19}$ Positive sign is expected for ethnic tensions variable since the ethnic tensions indicator receives higher score in more socially cohesive, less fractionalised countries with less risk of tensions.

${ }^{20}$ Recall Clague et al. (1999) shows CIM is reflecting contract enforcement and secure property rights by using case studies and by looking at its positive high correlations with measures of governance indicators. However, they never test the relationship between CIM and property rights empirically.

${ }^{21}$ Recall that North (2005) widens the usual approach to institutions with the concept of subjective mental model (such as belief -North calls it informal rules and constraints) which underlies its manifestation (i.e. explicit formal rules and constraints) This belief in turn defines the set of incentives and opportunities in a given society, and shapes economic actors'
} 
Finally, we investigate the channel through which social capital affects growth. In our second hypothesis we propose that social capital predicts growth through property rights environment in the countries under study. In the preceding models, we find corruption and ethnic tensions matter for growth as do political institutions, and their coefficients range from 0.002-0.005. By testing these variables against property rights index, we hope to find that they are indeed significant predictors of property rights with hopefully greater coefficients which will give empirical support to the proposed hypothesis. Such findings, therefore, would give evidence on the so-called "deep determinants" of growth in developing countries and prove that property rights institutions are only proximate determinant of growth.

The results in Table 7 show that three measures of social capital namely corruption, ethnic tensions and CIM emerge as significant predictors of property rights at a $1 \%$ level with the expected positive signs, either in individual or general model. Interestingly, their coefficients, which are between 0.160 and 6.395, are significantly larger than those in the growth estimations in Table 6. Their significance continues to hold in the presence of the political institutions variable, which is also significant in every model (with coefficients ranging between 0.109 and 0.199). These findings therefore confirm our proposition that social capital proxied by corruption, ethnic tensions and CIM is actually a deep determinant of growth and its effect on growth runs via property rights channel.

As for the corruption variable, it now has positive sign which means corruption determines property rights in a manner that is documented in the literature where less corrupted nation will have a more secure property rights environment and better contract enforcements. Recall corruption data used in this study is based on the corruption ranking given to the countries in the sample where least corrupted countries will receive higher score in the ranking. Since the corruption's size of coefficient in property rights estimation is much larger than that of growth estimation, therefore it is fairly appropriate to infer that true effect of corruption is actually growth-deterring instead of growth-inducing as it is earlier presumed based on the findings in growth model (see Table 6). The positive corruption effect in growth estimation found earlier, albeit smaller, could possibly be due to bad institutional quality in some of the developing countries under study ${ }^{22}$.

Furthermore, our finding on the positive significant CIM in the property rights estimations lends empirical support to the proposition by Clague et al. (1999) that CIM is a good proxy for contract enforcement and property rights ${ }^{23}$ This paper's empirical testing of the relationship between CIM and property rights could therefore be thought as an extension to Clague et al.'s work since they never tests the relationship between CIM and property rights empirically.

A comparison is made between the coefficients of social capital and political institutions variables (in model 37-41), and it reveals that social capital variables apparently have greater explanatory power than political institutions variable. This finding further confirms the primacy of North (2005)'s mental model (informal institutions) and somehow rejects the political (institutions) prominence theory by Acemoglu et al. (2005).

Although previously we find supporting evidence to the Acemoglu et al.'s political prominence theory (see Table 5 and discussion in page 15 third paragraph), it is apparently because of the lack of support

behaviour and decision making. Such a mental model, whether in those who are in the situation to dictate the rule of the games, or in those who have political power or holding political institutions, will determine the type of political constraints that eventually matter towards growth.

${ }^{22}$ This finding is in line with Mironov (2005)'s argument that corruption's effect on growth is conditional upon the countries' institutional quality. He shows that corruption is bad for growth in countries with good institutions, whereas in countries with poor institutions, corruption (he calls residual corruption) is positively related to growth.

${ }^{23}$ However, their conjecture that CIM is actually measuring the security of property rights and contract enforceability is simply based on observation and case studies. Clague et al. use country-based case studies and CIM correlations with measures of governance (or institutional) quality. When they find CIM is a significant predictor of income, growth and investment, and at the same time CIM has a high correlation with the governance measures and closely fluctuating together with the countries' political and economic uncertainties, 
to North's mental model due to the weakness of the social capital measure used in the analysis, i.e. generalized trust variable, whose effect on property rights is apparently obscured by the political variable.

The results in property rights estimations also partially confirm Williamson \& Kerekes (2011)'s findings on the underlying determinants of property rights. They find only informal institutions measured by culture i.e. trust, respect, individual self-determination and obedience are important to secure property rights and political constraints are not. We however find that both categories of institutions are significant determinants of property rights. 
Table 6: Fixed effect regression of growth model using trust-alternative variables



Note: Robust standard errors in parentheses. ***,**,* indicate the coefficient is significant at $1 \%, 5 \%$ and $10 \%$ respectively. 
Table 7: Fixed effect regression of property rights model using trust-alternative variables

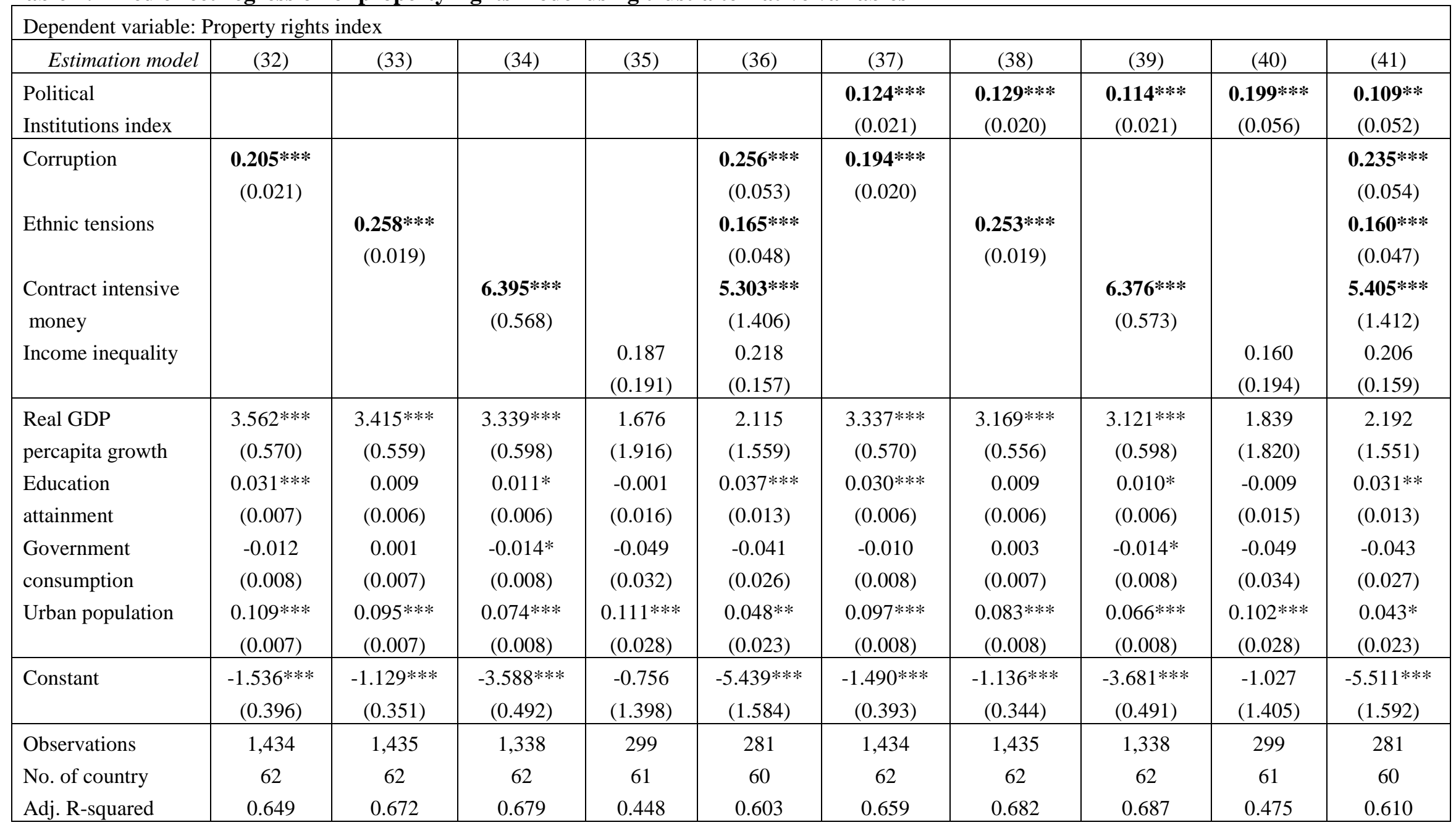

Note: Standard errors in parentheses. $* * *, * * *$ indicate the coefficient is significant at $1 \%, 5 \%$ and $10 \%$ respectively. 


\subsection{Endogenous corruption and Instrumental Variable (IV) estimation}

\section{Previous findings on corruption-growth relationship}

Generally, corruption has been shown to pose a significant threat to economic development. Corruption limits economic development by inhibiting growth in per capita income, causing detrimental impact on public and private investment, and reducing international trade in countries (see studies by Del Monte \& Papagni, 2001; Frankel, 1998; Habib \& Zurawicki, 2002; Mauro, 1995; Mo, 2001; Pellegrini \& Gerlagh, 2004; Tanzi \& Davoodi, 2002; Wei, 2000).

Nevertheless, the finding of positive corruption impact on growth especially in developing countries is not uncommon. Treisman (2007) shows that by casually looking at the international experience, some countries seem to have grown rapidly in recent decades despite the perception that their states were highly corrupt, for example, China, South Korea, Thailand, India and Indonesia ${ }^{24}$.

Bardhan (1997) in his review on corruption and development discusses efficiency-improving corruption that is particularly evident in developing countries with pervasive and cumbersome regulations. Aidt (2003) contends that corruption is a multi-faceted phenomenon as he outlines a distinction between four different categories of corruption and the first category is efficient corruption that arises to facilitate beneficial trade between agents that would not otherwise have been possible.

Empirically, Egger \& Winner (2005) find evidence of positive relationship of corruption to foreign direct investment. Mironov (2005) shows corruption is good for growth only in countries with poor institutions, and he argues in such countries corruption helps to "grease the wheels", allowing individuals to overcome burdensome red tape and bureaucratic inefficiency. Even though corruption reduces red tape, officials who expect bribes tend to set ex-ante levels of red tape above the socially optimal level. Therefore, one might find a positive effect of corruption by controlling for institution quality, even if the total effect of corruption on economic development is negative.

Mironov however highlights another possible explanation to this phenomenon i.e. economic growth might feed corruption by providing additional demand for bureaucrat services ${ }^{25}$. This undoubtedly points to an endogeneity problem that could be the underlying reason behind the negative coefficient of corruption. In other words, higher economic growth in the developing countries could have possibly encouraged the corruption practices. It is interesting to note that in spite of this contradicting result about corruption (we find growth-inducing effect of corruption although theoretically it should be growth-deterring), it is not possible to tell whether there is low trust level in the countries, or to say definitively that corruption is not a good measure of trust or trust is not good determinant of growth.

\section{Our findings of positive growth-effect of corruption}

As previously discussed, we find a significant growth-inducing impact of corruption as per our estimation using trust-alternative variables (see results in Table 6).

The hypothesis in this study is that the social capital determines growth, and the causation runs via formal institutional quality reflected by secure property rights environment. By using corruption as a measure of social capital, the direction of causation however is undoubtedly plagued by endogeneity problem as numerous studies have previously shown that income is one of the significant determinants of corruption (see for example (Seldadyo \& Haan, 2006; Treisman, 2007).

\footnotetext{
${ }^{24}$ Interestingly, all these countries are included in our sample of 69 developing countries.

25 There are numerous studies that show income as a significant determinant of corruption (income negatively related to corruption). Treisman (2007) argues that the strongest and most consistent finding in the empirical work is that higher economic development is closely related to lower perceived corruption. However Braun \& Di-Tella (2004) and Fréchette (2006) find income increases corruption and these studies employ panel fixed effects method, similar to our estimation technique.
} 
Earlier we acknowledge that the institutional variables are endogenous and to prevent reverse causation, all right-hand-side institutional variables, including social capital measures, are lagged by one-period. Nevertheless, the growth estimations augmented with corruption variable still yield negative coefficients for corruption which is not as hypothesized. This could probably be taken as an indication that endogeneity problem still exists, at least for corruption variable.

Therefore, to overcome the endogeneity problem of the corruption variable, we use an instrumental variable (IV) technique. By instrumenting corruption with an exogenous variable that satisfies the requirements of a good instrument, a robust direction of causation could be established. Normally A good instrument is an instrument variable satisfies the relevance and validity requirements if it has reasonably high correlation with the endogenous (instrumented) variable, and at the same time orthogonal to the idiosyncratic error of the original model.

\section{Instrumenting the endogenous corruption}

Previous studies have suggested a number of instruments for corruption including an ethno-linguistic fractionalization index (Mauro, 1995), legal origins (La Porta et al., 1999), and predicted trade shares (Shaw, Katsaiti, \& Jurgilas, 2011) ${ }^{26}$. However, these instruments are apparently not suitable to be used in panel analysis for obvious reason; they are time-invariant.

Although it is plausible to assume that formal institutional quality indicators (like regulatory quality, law and order, bureaucratic efficiency) and political institutions can be robust instruments for corruption $^{27}$, to use them as one seems to obscure the growth-impacts of such institutions in the first place. The fact that they determine corruption, and at the same time they are also among the significant predictors of growth, is apparently an ominous indication that the endogeneity problem would not be completely eliminated with the use of such variables as instruments.

Therefore, to find a good instrument which is relevant and valid is often difficult. Since this study uses corruption to measure trust-based social capital, an instrument for corruption therefore must be able to reflect some degree of trust too. We find a likely candidate for the corruption instrument is trade openness.

Intuitively, the more open an economy is, the more transactions are conducted between people unknown to each other (such as exporters and importers since they transact between people outside their countries), and this situation could not be achieved without some degree of trust among them.

Coyne \& Williamson (2009) empirically show that trade openness has positive significant impact on culture variables (including trust) ${ }^{28}$ and they argue that the more open a country is to trade, the more likely it is to possess a number of cultural traits (including high level of generalized trust) conducive to increased social and economic interactions. In other words, openness to international trade provides people with an increased number of opportunities for interaction and exchange which can generate trust through the development and cultivation of social relationships.

\footnotetext{
${ }^{26}$ Predicted trade share is developed by Frankel \& Romer (1999) based on gravity model of bilateral trade. Hall \& Jones (1999) use predicted trade share to instrument social infrastructure, but their social infrastructure is apparently not the "social capital" in true sense, since they measure it using index of government anti-diversion policies and trade openness. Kogel (2005) meanwhile points out that index of government anti-diversion policies is similar to measure of corruption used in Mauro (1995), hence the use of predicted trade share by Shaw et al. (2011) to instrument corruption looks natural.

${ }^{27}$ Seldadyo \& Haan (2006) propose that regulatory capacity is the most robust variable in explaining corruption. In their study, they examine 70 empirical determinants of corruption from economic, political, bureaucratic and regulatory, and geographical/cultural/religious categories. Via factor analysis they reduce these determinants into five new variables namely regulatory capacity, federalism, inequality, trade and political liberty.

28 They use Tabellini (2007)'s measure of culture which includes trust, respect, self-determination and obedience, and employ instrumental variable analysis for both the panel and cross sectional data to minimize reverse causality and endogeneity concerns.
} 
Meanwhile trade openness is also found to deter corruption, as shown by Larrain \& Tavares $(2007)^{29}$. They argue that trade openness normally encourages competition and competition leaves little room for corruption practices. In imperfect competitive markets where there is possibility of rents to be appropriatized and discretionary power of certain market players exceeds market outcomes, these situations open for the emergence of corruption practices.

In order to use trade openness as a relevant and valid instrument for corruption in a growth estimation, we must ensure that it is not impacting growth via any other way except through corruption (empirically speaking, it must be correlated with corruption but orthogonal to the error term in the growth estimation).

We test this using a simple OLS estimation of growth with trade openness as a regressor, in addition to the steady-state determinants and institutional variables. The results show that the trade openness variable is insignificant ${ }^{30}$. Therefore, trade openness variable satisfies necessary conditions to make it a relevant and valid instrument for corruption and IV estimation for endogenous corruption using trade openness as its exogenous instrument is then possible. We employ IV-two stage feasible GMM estimation which is robust in the presence of arbitrary heterokedasticity ${ }^{31}$. We also include auxiliary variables i.e. country dummies and a time trend to allow for overidentifying test ${ }^{32}$.

To check for an instrument relevance and validity criteria, IV-GMM estimation provide several tests for this purpose ${ }^{33}$. The parameter of interest is corruption in the second stage regression, particularly on the sign of the corruption coefficient. It is hoped that the sign will change to positive to show corruption's growth-deterring effect, in line with the convention.

In the first stage estimation, trade openness is estimated on the endogenous corruption variable, and the predicted value of corruption from the first stage estimation is then used in the second stage estimation. We have done multiple first stage estimations using trade openness as IV either it is individually included or combined with several other auxiliary variables ${ }^{34}$ in the model. The IV-GMM estimations on overall pass the identification and overidentifying restriction tests at random, and the predicted corruption variable in the second stage estimation is arbitrarily significant.

Only one thing remains i.e. the negative sign for the predicted corruption. Therefore, we take this as an indication that the endogeneity issue is not the reason behind such unconventional finding. Thus, we uphold our earlier argument that the finding of growth-inducing effect of corruption could possibly be due to apparently low institutional qualities in some of the developing countries under study. Furthermore, as we also find that corruption is a significant determinant of property rights in a manner

\footnotetext{
${ }^{29}$ Larrain \& Tavares (2007) use various measures of openness such as FDI share of GDP, export share of GDP, import share of GDP and export plus import share of GDP and they argue the finding is robust to inclusion of various control variables.

${ }^{30}$ The OLS estimation result is available upon request.

${ }^{31}$ Baum, Schaffer, \& Stillman (2003) shows that in the presence of heterokedasticity, the standard IV estimates of the standard errors are inconsistent and it prevents a valid inference be made. Furthermore, the usual form of diagnostics test for endogeneity and overidentifying restrictions are also invalid in the presence of heterokedasticity.

32 If only one instrument is used against one endogenous variable, overidentifying test will not work since the endogenous variable is exactly identified.

${ }^{33}$ To test for an instrument's relevance, F-test of the joint significance of the instruments in the first stage regression is used. This is particular sufficient in model with one endogenous variable, and the rule of thumb (for a single endogenous regressor) is that the F-test statistics must be 10 or larger. The relevance condition is also checked by under- and weak identification tests. Under-identification test is an LM test whether the equation is "identified" (i.e. whether the instruments are relevant) under the null hypothesis that the equation is under identified. Whereas weak identification test is done via Wald statistics under the null of the equation is weakly identified. In both tests, null must be rejected. In the presence of heterokedasticity, LM and Wald version of Kleibergen \& Paap (2006) $r k$ statistics are used. For instrument validity, Hansen J tests is used to test the null of the instruments are exogenous (orthogonality is fulfilled). Hansen $\mathrm{J}$ test is distributed as $\chi^{2}$ with degrees of freedom equal to the number of overidentifying restrictions (number of instrument - number of endogenous variable) (see Baum et al., 2003, and xtivreg2 help page in STATA program and also here: http://repec.org/bocode/x/xtivreg2.html).

${ }^{34}$ The auxiliary variables are such as trend and country dummies, trend squared and cubed, lags of corruption, and multiple lags of corruption.
} 
that conventionally documented by the literature, thus its growth-deterring impact is therefore assumed to run via property rights channel.

\section{Concluding remarks}

The primary objective of this study is to explain social capital effect on economic growth in developing countries in East Asia, Africa and Latin America for the period of 25 years (1984-2008). Using panel estimation technique which hitherto has been a rare case in social capital studies, we show that the most widely used measure of social capital namely generalized trust variable obtained from the WVS does not produce robust results in panel estimation. This is apparently due to the variable's limited data availability across years. If trust is omitted from the panel estimation with the assumption that it could be the underlying unobserved heterogeneity factor, the results of panel estimation of growth model improve significantly. This is however not the case in panel estimation of property rights model which arguably is an indication that the underlying unobserved heterogeneity factor for property rights could be other than trust.

Subsequently, we propose four trust-alternative variables namely corruption, ethnic tensions, contract intensive money (CIM) and income inequality to measure social capital. The results of this study provide a clearer picture to illustrate the significance of corruption, ethnic tensions and CIM as deep determinants of growth in the developing countries under study. These variables are found to have little or no direct effects towards growth, but their indirect effects operating via property rights channel are actually much larger. On the other hand, there is no evidence whatsoever on the significance of income inequality towards growth or property rights.

Overall, this study finds supporting evidence to the primacy of informal rules and constraints as proposed by North (2005) over the political prominence theory by Acemoglu et al. (2005). This study also partially confirms Williamson and Kerekes (2011)'s findings on the underlying determinants of property rights. Furthermore, this study is able to extend the work by Clague et al. (1999) to provide empirical support on the positive relationship between CIM and property rights institutions

To conclude, we believe more effort is needed in social capital literature particularly on the theoretical analysis to explore other possible channels through which social capital could have caused economic performance. Meanwhile, trust and other measures of social capital based on cross-country survey such as the World Value Survey and other similar surveys are apparently not suitable for advance econometric methodologies like panel estimation due to problem of data unavailability. 


\section{References:}

Acemoglu, D., \& Johnson, S. (2005). Unbundling Institutions. Journal of Political Economy, 113(5), 949-995.

Acemoglu, D., Johnson, S., \& Robinson, A. J. (2001). The Colonial Origins of Comparative Development: An Empirical Investigation. American Economic Review, 91(5), 1369-1401.

Acemoglu, D., Johnson, S., \& Robinson, J. A. (2005). Institutions as the Fundamental Cause of Long-Run Growth. In P.; Aghion \& S. Durlauf (Eds.), Handbook of Economic Growth (1st ed., Vol. 1, pp. 385-472). North Holland: Elsevier.

Ahmad, M., \& Hall, S. G. (2012). Institutions and growth: Testing the spatial effect using weight matrix based on the institutional distance concept. MPRA Paper. Retrieved from http://ideas.repec.org/p/pra/mprapa/42294.html

Aidt, T. S. (2003). Economic analysis of corruption: a survey. Economic Journal Royal Economic Society, 113(491), F632-F652.

Aron, J. (2000). Growth and Institutions: A Review of the Evidence. The World Bank Research Observer, 15(I), 99-135. doi:10.1093/wbro/15.1.99

Baliamoune-Lutz, M. (2009a). Human well-being effects of institutions and social capital. Contemporary Economic Policy, 27(1), 54-66.

Baliamoune-Lutz, M. (2009b). Institutions, trade, and social cohesion in fragile states: implications for policy conditionality and aid allocation. Journal of Policy Modeling, 31(6), 877-890.

Baliamoune-Lutz, M. (2011). Trust-based social capital, institutions, and development. Journal of SocioEconomics, 40(4), 335-346.

Bardhan, P. (1997). Corruption and Development: A Review of Issues. Journal of Economic Literature, XXXV, $1320-1346$.

Barro, R. J., \& Lee, J. W. (2010). A New Data Set of Educational Attainment in the World 1950-2010. National Bureau of Economic Research Working Paper Series, No, 15902.

Baum, C. F., Schaffer, M. E., \& Stillman, S. (2003). Instrumental Variables and GMM Estimation and Testing. The Stata Journal, 3(1), 1-31.

Beck, T., Clarke, G., Groff, A., Keefer, P., \& Walsh, P. (2001). New Tools in Comparative Political Economy: The Database of Political Institutions. World Bank Economic Review Vol 15, No, 1, 165-176.

Berggren, N., Elinder, M., \& Jordahl, H. (2008). Trust and growth: A shaky relationship. Empirical Economics, $35(2), 251-274$

Beugelsdijk, S., de Groot, F. H. L., \& van Schaik, A. B. T. M. (2004). Trust and Economic Growth: a robustness test. Oxford Economic Papers, 56, 118-134.

Beugelsdijk, S., \& van Schaik, T. (2005). Social capital and growth in European regions: an empirical test. European Journal of Political Economy, 21, 301-324.

Bjørnskov, C. (2006). How Does Social Trust Affect Economic Growth? (No. Working Paper: 06-2). University of Aarhus, Aarhus School of Business. 
Bjørnskov, C., \& Svendsen, G. T. (2003). Measuring Social Capital: Is There a Single Underlying Explanation? (No. Working Paper: 03-5). Department of Economics, Aarhus School of Business.

Braun, M., \& Di-Tella, R. (2004). Inflation, Inflation Variability, and Corruption. Economics and Politics, 16, $77-100$.

Chang, C. C. E., \& Chu, Y. (2006). Corruption and trust: Exceptionalism in Asian Democracies? The Journal of Politics, 68(2), 259-271.

Clague, C., Keefer, P., Knack, S., \& Olson, M. (1999). Contract intensive money: contract enforcement, property rights, and economic performance. Journal of Economic Growth, 4(2), 185-211.

Coleman, J. S. (1988). Social Capital in the Creation of Human Capital. American Journal of Sociology, 94, 95120.

Coleman, J. S. (1990). The Foundations of Social Theory. Cambridge, MA: Harvard University Press.

Coyne, C., \& Williamson, C. R. (2009). Trade Openness and Culture (No. Working Paper:09-05). Department of Economics, West Virginia University.

Del Monte, A., \& Papagni, E. (2001). Public expenditure, corruption, and economic growth: the case of Italy,. European Journal of Political Economy, 17, 1-16.

Dincer, O., \& Uslaner, E. (2010). Trust and growth. Public Choice, Springer, 142(1), 59-67.

Durlauf, S. N., \& Fafchamps, M. (2005). Social Capital. Handbook of Economic Growth, 1, 1639-1699.

Easterly, W. (2006). Social Cohesion, Institutions and Growth. Center for Global Development, Working Paper No, 94.

Easterly, W., Ritzen, J., \& Woolcock, M. (2006). Social Cohesion, Institutions, and Growth. Economics and Politics, 18(2), 103-120.

Egger, P., \& Winner, H. (2005). Evidence on corruption as an incentive for foreign direct investment. European Journal of Political Economy, 21(4), 932-952.

Frankel, G. A. (1998). The Asian Model, the Miracle, the Crisis and the Fund. Address to the US Trade Commission, 16.

Frankel, J. A., \& Romer, D. (1999). Does Trade Cause Growth? American Economic Review, 89(3), 379-399.

Fréchette, G. R. (2006). Panel Data Analysis of the Time-Varying Determinants of Corruption (No. CIRANO Working Paper: 2006-28). CIRANO.

Fukuyama, F. (1999). The Great Disruption. , Simon and Schuster, New York.

Gastil, R. D. (1978). Freedom in the World. Political rights dataset, The Freedom House.

Glaeser, E. L., La Porta, R., Lopez-de-Silanes, F., \& Shleifer, A. (2004). Do Institutions Cause Growth? Journal of Economic Growth, 9(3), 271-303.

Habib, M., \& Zurawicki, L. (2002). Corruption and foreign direct investment,. Journal of International Business Studies, 33, 291-307. 
Hall, R. E., \& Jones, C. I. (1999). Why Do Some Countries Produce So Much More Output per Worker Than Others? The Quarterly Journal of Economics, 114, 83-116.

Hall, S. G., \& Ahmad, M. (2013). Can Trust Explain Social Capital Effect on Property Rights and Growth? Procedia Economics and Finance, 7, 55-64. doi:10.1016/S2212-5671(13)00218-9

Helliwell, J. F. (1996). Economic Growth and Social Capital in Asia. NBER Working Paper 5470, National Bureau of Economic Research., Cambridge, MA.

Henisz, W. J. (2010). Political Constraint Index Dataset. Retrieved from http://wwwmanagement.wharton.upenn.edu/henisz/

Heston, A., Summers, R., \& Aten, B. (2009). Penn World Table Version 6.3. Center for International Comparisons of Production, Income and Prices at the University of Pennsylvania.

Kleibergen, F., \& Paap, R. (2006). Generalized reduced rank tests using the singular value decomposition. Journal of Econometrics, 133(1), 97-126.

Knack, S., \& Keefer, P. (1997). Does Social Capital Have an Economic Payoff? A Cross-Country Investigation. Quarterly Journal of Economics, 112(4), 1251-1288.

Knowles, S. (2005). The future of social capital in development economics research. Paper for the WIDER Jubilee Conference: Thinking\} Ahead: The Future of Development Economics, Helsinki 17-18 June.

Knowles, S. (2006). Is Social Capital Part of the Institutions Continuum\} and is it a Deep Determinant of Development? (No. Working Papers: RP2006/25). World Institute for Development Economic Research (UNU-WIDER).

Kogel, T. (2005). Youth Dependency and Total Factor Productivity. Journal of Development Economics, 76(1), $147-173$.

La Porta, R., Lopez-de-Silanes, F., Shleifer, A., \& Vishny, R. W. (1999). Trust in Large Organizations. In P. Dasgupta \& I. Seregaldin (Eds.), Social Capital - A Multifaceted Perspective (pp. 310-324). Washingto DC: The World Bank.

Larrain, B. F., \& Tavares, J. (2007). Can Openness Deter Corruption? The Role of Foreign Direct Investment (No. CEPR Working Paper: 6488). Centre of Economic Policy and Research.

Mankiw, G. N., Romer, D., \& Weil, D. N. (1992). A Contribution to the Empirics of Economic Growth. The Quarterly Journal of Economics, 107(2), 407-437.

Marshall, M. G., \& Jaggers, K. (2008). Polity \{IV\} Project: Political Regime Characteristics and Transitions, 1800-2008, Center for Systemic Peace and Colorado State University.

Mauro, P. (1995). Corruption and Growth. Quarterly Journal of Economics, 107, 407-437.

Mironov, M. (2005). Bad Corruption, Good Corruption and Growth. University of Chicago. Mimeo.

Mo, P. H. (2001). Corruption and growth. Journal of Comparative Economics, 29, 66-79.

Morris, S. D., \& Klesner, J. L. (2010). Corruption and Trust: Theoretical Considerations and Evidence from Mexico. Comparative Political Studies, XX(x), 1-28. 
Neira, I., Vászquez, E., \& Portela, M. (2009). An empirical analysis of social capital and economic growth in Europe (1980-2000). Social Indicators Research, 92(1), 111-129.

North, D. C. (2005). Understanding the Process of Economic Change. Princeton: Princeton University Press.

Pellegrini, L., \& Gerlagh, R. (2004). Corruption's effect on growth and its transmission channels. Kyklos, 57, $429-456$.

Pérez-García, M. F. S. L., Montesinos, S. V., \& Fernandez de Guevara Radoselovics, J. (2006). Measurement of Social Capital and Growth: An Economic Methodology. Fundacion BBVA, Documentos de Trabajo 4/2006.

PRS Group, T. (2009). International Country Risk Guide, Political risk dataset. (2009th ed.).

Putnam, R. D. (1993). Making Democracy Work. (with Robert Leonard and Raffaella Y. Nanetti), Princeton: Princeton University Press.

Raiser, M. (2008). Social capital and economic performance in transition economies. In D. Castiglione, J. W. v Deth, \& G. Wolleb (Eds.), The Handbook of Social Capital (pp. 491-519). Oxford: Oxford University Press.

Ritzen, J., Easterly, W., \& Woolcock, M. (2000). On Good Politicians and Bad Policies: Social Cohesion, Institutions, and Growth. The World Bank.

Rodrik, D. (1999). Where did all the growth go? External shocks, social conflicts, and growth collapses. Journal of Economic Growth, 4(4), 385-412.

Rodrik, D. (2005). Growth Strategies. Handbook of Economic Growth, 1, 967-1014.

Rodrik, D. (2008). Second-Best Institutions. American Economic Review, 98(2), 100-104.

Rodrik, D., \& Rosenzweig, M. (2009). Linking development policy and development research: an introduction. In R. D. \& R. M. (Eds.), Handbook of Development Economics (Vol. 5).

Rodrik, D., Subramaniam, A., \& Trebbi, F. (2004). Institutions Rule: The Primacy of Institutions Over Geography and Integration in Economic Development. Journal of Economic Growth, 9(2), 131-165.

Roth, F. (2009). Does Too Much Trust Hamper Economic Growth? Kyklos, 62(1), 103-128.

Rothstein, B., \& Uslaner, E. M. (2005). All for all: Equality and Social Trust (No. LSE Health and Social Care Discussion Paper: 15). London School of Economics and Political Science.

Seldadyo, H., \& Haan, J. D. (2006). The Determinants of Corruption: A Literature Survey and New Evidence. Paper Prepared for the 2006 EPCS Conference, Turku, Finland, 20-23 April.

Serageldin, I. (1999). Foreword. In S. Knack (Ed.), Social Capital, Growth and Poverty: A Survey of CrossCountry Evidence (p. iii). Social Capital Initiative Working Paper 7.

Shaw, P., Katsaiti, M.-S., \& Jurgilas, M. (2011). Corruption and Growth Under Weak Identification. Economic Inquiry, 49, 264-275.

Sobel, J. (2002). Can we trust social capital? Journal of Economic Literature, 40, 139-154. 
Stiglitz, J. E. (2000). Keynote Adress: Challenge in the analysis of the role on institutions in economic development. In B. Kodendorfer-Lucius, G., and Pleskovic (Ed.), The Institutional Foundation of a Market Economy (pp. 15-20). Villa Borsig Workshop Series 2000, German Foundation for (DSE).

Tabellini, G. (2007). Culture and Institutions (No. CEPR Discussion Papers: 6589). Centre of Economic Policy and Research.

Tabellini, G. (2010). Culture and Institutions: Economic Development in the Regions of Europe. Journal of the European Economic Association, 8(4), 677-716.

Tanzi, V., \& Davoodi, H. (2002). Corruption, growth and public finances. In G. Abed \& S. Gupta (Eds.), Governance, Corruption, and Economic Performance (pp. 197-222). International Monetary Fund, Washington DC.

Treisman, D. (2007). What Have We Learned about the Causes of Corruption from Ten Years of Cross-National Empirical Research. Annual Review of Political Science, 10, 211-244.

Wei, S. (2000). How taxing is corruption on international investors? Review of Economics and Statistics, 82, 111.

Westlund, H., \& Adam, F. (2010). Social capital and Economic Performance: A Meta-analysis of 65 studies. European Planning Studies, 18(6), 893-919.

Whiteley, P. F. (2000). Economic Growth and Social Capital. Political Studies, 48, 443-466.

Williamson, C. R., \& Kerekes, C. B. (2011). Securing Private Property: Formal versus Informal Institutions. Journal of Law and Economics, 54(3), 537-572.

World Bank, T. (2009). World Development Indicators (Various Ed.). Manchester: ESDS International, University of Manchester.

World Values Survey, T. (2009). World Values Survey 1981-2008 Official Aggregate v. Aggregate File Producer ASEP/JDS.

Zak, J. P., \& Knack, S. (2001). Trust and Growth. Economic Journal, 111, 295-321. 


\section{Appendix 1: Table A}

Summary of institutional variables' conceptual definition and sources of data

\begin{tabular}{|c|c|c|c|c|}
\hline No. & Variable name & Conceptual definition & Measurement of & Sources of data \\
\hline 1. & $\begin{array}{l}\text { Investment } \\
\text { Profile }\end{array}$ & $\begin{array}{l}\text { An assessment on factors affecting the risk to investment from the aspect } \\
\text { of contract viability and expropriation, profits repatriation and payment } \\
\text { delays. This is a merged version of two ICRG indicators (IRIS dataset) } \\
\text { namely Repudiation of Contracts by Government, and Risk of } \\
\text { Expropriation (Knack and Keefer, 2005) }\end{array}$ & \multirow{4}{*}{$\begin{array}{l}\text { Index of security of } \\
\text { property rights (a simple } \\
\text { average of the scores of the } \\
\text { four indicators) }\end{array}$} & \multirow{4}{*}{$\begin{array}{l}\text { International Country Risk } \\
\text { Guide (ICRG) - The PRS } \\
\text { Group (2009) }\end{array}$} \\
\hline 2. & Law and Order & $\begin{array}{l}\text { An assessment of the strength and impartiality of the legal system, and } \\
\text { public observance of the law. }\end{array}$ & & \\
\hline 3. & $\begin{array}{l}\text { Bureaucracy } \\
\text { Quality }\end{array}$ & $\begin{array}{l}\text { An assessment of possible drastic policy changes when governments } \\
\text { change. Strong bureaucracy has the strength and expertise to govern } \\
\text { without drastic changes in policy or interruptions in government services } \\
\text { and it tends to be somewhat autonomous from political pressure and have } \\
\text { an established mechanism for recruitment and training. }\end{array}$ & & \\
\hline 4. & $\begin{array}{l}\text { Government } \\
\text { Stability }\end{array}$ & $\begin{array}{l}\text { An assessment on the government's ability to carry out its declared } \\
\text { program(s) and its ability to stay in office based on criteria like } \\
\text { government unity, legislative strength and public support. }\end{array}$ & & \\
\hline 5. & Polity2 & $\begin{array}{l}\text { An indicator that measures key qualities in executive recruitment, } \\
\text { constraints on executives, and political competition. It gives indication } \\
\text { whether a regime is an institutionalised democracy or institutionalised } \\
\text { autocracy or anocracies (mixed, or incoherent, authority regimes). }\end{array}$ & \multirow{4}{*}{$\begin{array}{l}\text { Index of Political } \\
\text { Institutions } \\
\text { (a simple average of the } \\
\text { scores of the four } \\
\text { indicators) }\end{array}$} & $\begin{array}{l}\text { Polity IV - Marshall and } \\
\text { Jaggers (2008) }\end{array}$ \\
\hline 6. & Political Rights & $\begin{array}{l}\text { An indicator that assesses the factors that enable people to participate } \\
\text { freely in the political process, including through the right to vote, compete } \\
\text { for public office, and elect representatives who have a decisive impact on } \\
\text { public policies and are accountable to the electorate. }\end{array}$ & & $\begin{array}{l}\text { Freedom in the World (also } \\
\text { known as Gastil index) - } \\
\text { Gastil (1978) }\end{array}$ \\
\hline 7. & Polcon3 & $\begin{array}{l}\text { The indicator takes into account the number of veto points faced by the } \\
\text { executive power, as well as the distribution of political preferences across } \\
\text { different branches of government. More alignment across branches of } \\
\text { government increases the feasibility of policy change and implies less } \\
\text { political constraints for the executive. The political constraints measure is } \\
\text { derived in a spatial model under the assumption that the status quo policy } \\
\text { is uniformly distributed over the policy space [0,1]. The minimum is a } \\
\text { value of } 0 \text {, which implies no constraints and absolute political discretion } \\
\text { for the executive. }\end{array}$ & & $\begin{array}{l}\text { The Political Constraint Index } \\
\text { (POLCON) database - Henisz } \\
(2010)\end{array}$ \\
\hline 8. & Checks & $\begin{array}{l}\text { This variable draws on several variables within the DPI to construct an } \\
\text { index of checks and balances in the political system. While the variables } \\
\text { do not necessarily reflect the informal constraints on electoral competition }\end{array}$ & & $\begin{array}{l}\text { Database of Political } \\
\text { Institutions by the World } \\
\text { Bank - Beck et al. }(2001)\end{array}$ \\
\hline
\end{tabular}




\begin{tabular}{|c|c|c|c|c|}
\hline & & $\begin{array}{l}\text { or executive authority, they allow researchers to identify the extent of } \\
\text { formal constitutional control on political decision makers. }\end{array}$ & & \\
\hline 9. & Corruption & $\begin{array}{l}\text { An assessment of corruption within the political system. Such corruption is } \\
\text { a threat to foreign investment for several reasons: it distorts the economic } \\
\text { and financial environment; it reduces the efficiency of government and } \\
\text { business by enabling people to assume positions of power through } \\
\text { patronage rather than ability; and, last but not least, introduces an inherent } \\
\text { instability into the political process. The most common form of corruption } \\
\text { met directly by business is financial corruption in the form of demands for } \\
\text { special payments and bribes connected with import and export licenses, } \\
\text { exchange controls, tax assessments, police protection, or loans. }\end{array}$ & \multirow{4}{*}{ Trust-alternative variables } & \multirow{2}{*}{$\begin{array}{l}\text { International Country Risk } \\
\text { Guide (ICRG) - The PRS } \\
\text { Group (2009) }\end{array}$} \\
\hline 10. & Ethnic tensions & $\begin{array}{l}\text { An assessment of the degree of tension within a country attributable to } \\
\text { racial, nationality, or language divisions. Lower ratings are given to } \\
\text { countries where racial and nationality tensions are high because opposing } \\
\text { groups are intolerant and unwilling to compromise. Higher ratings are } \\
\text { given to countries where tensions are minimal, even though such } \\
\text { differences may still exist. }\end{array}$ & & \\
\hline 11. & $\begin{array}{l}\text { Contract } \\
\text { intensive } \\
\text { money }\end{array}$ & $\begin{array}{l}\text { As a measure of the security of contract enforcement and property rights, } \\
\text { CIM support the claim that only countries where governments give private } \\
\text { parties the capacity to make credible commitments that they could not } \\
\text { otherwise make, and thereby achieve gains from trade that they could not } \\
\text { otherwise obtain, achieve their economic potential. The importance of } \\
\text { CIM is based on the following three propositions: (1) the contract- } \\
\text { intensive money ratio is a measure of the proportion of transactions that } \\
\text { rely on third-party enforcement; (2) this proportion is a good indicator of } \\
\text { the reliability of contract } 28 \text { enforcement and the security of property } \\
\text { rights in countries; and (3) contract enforcement reliability and property } \\
\text { rights security are important for high levels of productivity and rapid } \\
\text { economic growth. }\end{array}$ & & $\begin{array}{l}\text { Measure: M2-C)/M2 } \\
\text { where } \\
\text { M2=broad definition of } \\
\text { money supply, and } \\
\text { C=currency held outside } \\
\text { banks. } \\
\text { Data on M2 and C are } \\
\text { obtained from Datastream and } \\
\text { World Development Indicator } \\
\text { (WDI) of the World Bank } \\
\text { (2009) }\end{array}$ \\
\hline 13. & $\begin{array}{l}\text { Income } \\
\text { inequality }\end{array}$ & $\begin{array}{l}\text { Gini index measures the extent to which the distribution of income or } \\
\text { consumption expenditure among individuals or households within an } \\
\text { economy deviates from a perfectly equal distribution. A Lorenz curve } \\
\text { plots the cumulative percentages of total income received against the } \\
\text { cumulative number of recipients, starting with the poorest individual or } \\
\text { household. The Gini index measures the area between the Lorenz curve } \\
\text { and a hypothetical line of absolute equality, expressed as a percentage of } \\
\text { the maximum area under the line. Thus a Gini index of } 0 \text { represents perfect } \\
\text { equality, while an index of } 100 \text { implies perfect inequality. }\end{array}$ & & $\begin{array}{l}\text { World Development Indicator } \\
\text { (WDI) of the World Bank } \\
(2009)\end{array}$ \\
\hline
\end{tabular}


